\title{
Elemental Analysis of Desert Varnish Samples in the Vicinity of Coal- Fired Power Plants and the Nevada Test Site Using Laser Ablation ICP- MS
}

\author{
Piotr Nowinski ${ }^{*}, 1$, Vernon F. Hodge ${ }^{2}$, Kazumasa Lindley ${ }^{2}$ and James V. Cizdziel ${ }^{3}$ \\ ${ }^{I}$ Department of Air Quality and Environmental Management, Clark County, Nevada, USA \\ ${ }^{2}$ Department of Chemistry, University of Nevada, Las Vegas, 4505 S. Maryland Parkway, NV 89154, USA \\ ${ }^{3}$ Department of Chemistry and Biochemistry, University of Mississippi, University, MS 38677, USA
}

\begin{abstract}
Desert varnish is a thin manganese-iron rich dark coating that forms on rocks most often in arid climates. This coating may be up to a few hundred microns in thickness and is thought to grow by approximately one micron per thousand years. Recent research has shown that many elements are incorporated into this coating, and, in spite of its slow growth, it may serve as a passive environmental monitor for recent and historical air pollution. To test this hypothesis, small pieces of varnished rock were probed directly by laser ablation inductively coupled plasma mass spectrometry (LAICPMS). Results were obtained for 11 elements (13 isotopes: ${ }^{9} \mathrm{Be},{ }^{107} \mathrm{Ag},{ }^{111} \mathrm{Cd},{ }^{118} \mathrm{Sn},{ }^{121} \mathrm{Sb},{ }^{138} \mathrm{Ba},{ }^{184} \mathrm{~W},{ }^{205} \mathrm{Tl},{ }^{206} \mathrm{~Pb}$, ${ }^{207} \mathrm{~Pb},{ }^{208} \mathrm{~Pb},{ }^{232} \mathrm{Th}$, and ${ }^{238} \mathrm{U}$ ) by magnetic sector ICPMS and for 23 elements (25 isotopes: same as before plus ${ }^{51} \mathrm{~V},{ }^{52} \mathrm{Cr}$, ${ }^{59} \mathrm{Co},{ }^{60} \mathrm{Ni},{ }^{65} \mathrm{Cu},{ }^{66} \mathrm{Zn},{ }^{88} \mathrm{Sr},{ }^{98} \mathrm{Mo},{ }^{115} \mathrm{In},{ }^{133} \mathrm{Cs},{ }^{197} \mathrm{Au}$, and ${ }^{209} \mathrm{Bi}$ ) by quadrupole ICPMS. Varnished rock samples were collected mainly in the fallout patterns of two coal-fired power plants and downwind from the Nevada Test Site (NTS). The LA-ICPMS data indicate that many of the elements commonly found in fly ash from coal-fired power plants (e.g., Cr, $\mathrm{Co}, \mathrm{Ni}, \mathrm{Cu}, \mathrm{Zn}, \mathrm{Cd}, \mathrm{Sn}, \mathrm{Sb}, \mathrm{Tl}$ and $\mathrm{Pb}$ ) were highly enriched in the rock coatings in relation to the upper continental crust (UCC). For one of the power plants, where tracer plume studies had been carried out, the highest concentrations in the rock varnish coincide with the peak tracer concentration locations. Thus, these elements in rock varnish hold promise for identifying those geographical regions impacted by nearby power plants. Overall, the results indicate that rock varnish can be used as a passive environmental monitor of relatively recent events, and that the trace element fingerprints held in rock varnish may also hold much potential in forensic air pollution studies.
\end{abstract}

Keywords: Desert varnish, coal-fired power plants, laser ablation, ICPMS, metals.

\section{INTRODUCTION}

Rock surfaces are often covered with a dark coating called rock varnish or desert varnish. Many ancient peoples produced petroglyphs or primitive writings by scratching through this coating to expose the much lighter rock substrate. Rock varnish accumulates on exposed rock surfaces in all terrestrial environments, including tropicaland polar-regions, but is most common in deserts [1]. The mechanism for its formation is not fully understood, however, these thin films (up to a few hundred $\mu \mathrm{m}$ ), are thought to be slow-growing $(\sim 1 \mu \mathrm{m} / 1000 \mathrm{yr})$ and consist of layers of clay minerals cemented together to the substrate rock by Fe-Mn oxyhydroxides [2]. Most researchers suggests that the ingredients of desert varnish are derived from the atmosphere and these coatings can effectively capture and retain relatively recent air pollutants, including heavy metals and radionuclides [3-9].

Tebo et al. [10] and Thiagarajan and Lee [11] noticed that the relative abundances of the elements in varnish films appear to reflect their solubilities in water or their tendency

*Address correspondence to this author at the Air Quality and Environmental Management, Clark County, Nevada, USA; Tel: +1-702-455-3529; Fax: +1702-383-9994; E-mail: Nowinski@co.clark.nv.us for being scavenged by Fe-Mn oxyhydroxides. Thiagarajan and Lee [11] report the extreme relative depletions of rubidium $(\mathrm{Rb})$ and cesium $(\mathrm{Cs})$ in varnishes relative to the upper continental crust (UCC) in the samples collected in the Mojave Desert and Death Valley, California. They proposed that $\mathrm{Rb}$ and $\mathrm{Cs}$ are probably leached from the airborne dust particles before the particles are incorporated into the varnish films. The authors also observed relative enrichments in rareearth elements (REE), $\mathrm{Co}, \mathrm{Ni}$, and $\mathrm{Pb}$ in varnishes and suggested that these enrichments are consistent with the susceptibility of these elements for adsorption by $\mathrm{Fe}-\mathrm{Mn}$ oxyhydroxides.

Wayne et al. [12] suggest that elevated trace metal concentrations on the varnish surfaces may be directly attributed to metal-containing, atmospherically-deposited particulates and that these particulates probably originated at coal-fired power plants. The particulate matter (PM) emissions from coal-fired power plants are typically controlled with electrostatic precipitators (ESP) or fabric filters [13]. These units routinely achieve 99\% control efficiency. However, the finest particles in the fly ash are not removed by the pollution control equipment and are emitted with the flue gases to the atmosphere. The authors conclude that trace metals can be retained in the rock varnish, and thus, provide a record of ambient airborne pollution. 
In the presented work, we evaluate the use of LA-ICPMS for direct (in situ) analysis of elements in desert varnish samples collected in the areas impacted by sources of air pollution. Elevated levels of metals in the varnish samples could indicate possible contamination and provide help in mapping the distribution of air pollution. This paper discusses the results found for the LA-ICPMS analysis of desert varnish samples.

\section{MATERIALS AND METHODOLOGY}

\subsection{Sampling Sites and Sample Collection}

The point sources of air pollution in this study were chosen because of: (1) their history of atmospheric emissions and (2) the availability of reports documenting geographic deposition patterns or dispersal of their contamination [14]. The selected sources include: the Nevada Test Site (NTS); the Mohave Power Project (MPP), Laughlin, Nevada; the Reid Garner Power Plant (RGPP), Moapa, Nevada; and the Titanium Metals Corporation, Inc. (TIMET), Henderson, Nevada. Detailed sample site information is given in Table $\mathbf{1}$. A map showing locations of the sites is provided in Fig. (1).

The NTS is a United States Department of Energy (US DOE) reservation, located about $105 \mathrm{~km}$ northwest of Las Vegas, Nevada. The site was established in 1951 for the testing of nuclear weapons, and is composed of approximately $3,500 \mathrm{~km}^{2}$ of desert and mountainous terrain. From January 1951 till the end of October 1958, about 100 aboveground nuclear tests took place at the NTS [15]. The prevailing weather patterns at the time of the testing dispersed most of the fallout to the north and east of the NTS. Little direct fallout was blown toward Las Vegas [15].

The MPP was a 1580 megawatt (MW) coal-fired power plant located in Laughlin, Nevada, approximately $120 \mathrm{~km}$ southwest of Grand Canyon National Park (GCNP). The plant operated from 1971 to 2005 and emitted up to 40,000 tons of sulfur dioxide $\left(\mathrm{SO}_{2}\right)$ per year, making it the largest source of $\mathrm{SO}_{2}$ in the Western United States [14]. The MPP was shut down in December of 2005, in part because plumetracer studies implicated it as an important source of haze in the GCNP [14]. Thus, seasonal plumes for the MPP have been mapped, and, since fly-ash is a possible source of heavy metals, samples of desert varnish were collected at locations in the MPP plumes $[16,17]$.

The RGPP is a $650 \mathrm{MW}$ coal-fired electric generation facility operated by the Nevada Energy, Las Vegas, Nevada [18]. The RGPP is located approximately $2 \mathrm{~km}$ southwest of the city of Moapa, Nevada and approximately $90 \mathrm{~km}$ northwest of Las Vegas. The facility has operated

Table 1. List of the Sampling Sites with the Distance $(\mathrm{km})$ from Power Plant

\begin{tabular}{|c|c|c|c|c|c|}
\hline Site & Geographical Name & Distance (km) & Latitude & Longitude & Altitude (ft) \\
\hline NTS 1 & Queen City Summit, Rachel, NV & $171 \mathrm{~km}$ North of RGPP & N $37^{\circ} 45.905^{\prime}$ & W $115^{\circ} 57.940^{\prime}$ & 5.742 \\
\hline NTS 2 & Hancock Summit, Crystal Springs, NV & 109 km North of RGPP & $\mathrm{N} 37^{\circ} 26.812^{\prime}$ & $\mathrm{W} 115^{\circ} 22.264^{\prime}$ & 5.305 \\
\hline NTS 3 & Pahranagat Valley, Alamo, NV & $83 \mathrm{~km}$ North of RGPP & $\mathrm{N} 37^{\circ} 18.572^{\prime}$ & W $115^{\circ} 0.7419^{\prime}$ & 3.404 \\
\hline TIMET 1 & Henderson, NV & $108 \mathrm{~km}$ North of MPP & $\mathrm{N} 36^{\circ} 02.895^{\prime}$ & $\mathrm{W} 114^{\circ} 59.361^{\prime}$ & 1.796 \\
\hline TIMET 2 & Black Mountain, Henderson, NV & $112 \mathrm{~km}$ North of MPP & $\mathrm{N} 36^{\circ} 01.257^{\prime}$ & W $115^{\circ} 00.792^{\prime}$ & 2.113 \\
\hline TIMET 3 & Henderson, NV & $113 \mathrm{~km}$ North of MPP & $\mathrm{N} 36^{\circ} 03.274^{\prime}$ & W $115^{\circ} 000.582^{\prime}$ & 1.699 \\
\hline TIMET 4 & Henderson. NV & $114 \mathrm{~km}$ North of MPP & $\mathrm{N} 36^{\circ} 04.308^{\prime}$ & W $115^{\circ} 20.393^{\prime}$ & 1.69 \\
\hline MPP 1 & Las Vegas Wash, Henderson, NV & $107 \mathrm{~km}$ North of MPP & N $36^{\circ} 04.432^{\prime}$ & $\mathrm{W} 114^{\circ} 55.603^{\prime}$ & 1.719 \\
\hline MPP 2 & Cottonwood Cove, Searchlight, NV & $43 \mathrm{~km}$ North of MPP & $\mathrm{N} 35^{\circ} 29.000^{\prime}$ & $\mathrm{W} 114^{\circ} 44.491^{\prime}$ & 1.504 \\
\hline MPP 3 & Dolan Springs, AZ & $53 \mathrm{~km}$ North of MPP & $\mathrm{N} 35^{\circ} 35.069^{\prime}$ & $\mathrm{W} 114^{\circ} 17.126^{\prime}$ & 3.27 \\
\hline MPP 4 & Laughlin, NV & $3 \mathrm{~km}$ North of MPP & $\mathrm{N} 35^{\circ} 09.074^{\prime}$ & $\mathrm{W} 114^{\circ} 38.251^{\prime}$ & 1.061 \\
\hline MPP 5 & Lake Havasu, AZ & $58 \mathrm{~km}$ South of MPP & N $34^{\circ} 37.612^{\prime}$ & $\mathrm{W} 114^{\circ} 19.525^{\prime}$ & 1.39 \\
\hline MPP 6 & Cattail Cove State Park, AZ & $92 \mathrm{~km}$ South of MPP & $\mathrm{N} 34^{\circ} 21.564^{\prime}$ & $\mathrm{W} 114^{\circ} 09.597^{\prime}$ & 613 \\
\hline MPP 7 & Chiquita Hills, NV & $22 \mathrm{~km}$ North of MPP & N $35^{\circ} 09.629^{\prime}$ & W $114^{\circ} 50.099^{\prime}$ & 2.58 \\
\hline MPP 8 & Chemehuei Valley, CA & $70 \mathrm{~km}$ South of MPP & $\mathrm{N} 34^{\circ} 35.452^{\prime}$ & $\mathrm{W} 114^{\circ} 38.185^{\prime}$ & 1.95 \\
\hline MPP 9 & Parker Dam, AZ & $123 \mathrm{~km}$ South of MPP & $\mathrm{N} 34^{\circ} 17.498^{\prime}$ & $\mathrm{W} 114^{\circ} 07.782^{\prime}$ & 610 \\
\hline MPP 10 & Earp, CA & $126 \mathrm{~km}$ South of MPP & N $34^{\circ} 10.713^{\prime}$ & $\mathrm{W} 114^{\circ} 15.621^{\prime}$ & 417 \\
\hline RGPP 1 & Elgin, NV & $80 \mathrm{~km}$ North of RGPP & N $37^{\circ} 22.723^{\prime}$ & $\mathrm{W} 114^{\circ} 32.993^{\prime}$ & 3.501 \\
\hline RGPP 2 & Moapa, NV & $2 \mathrm{~km}$ North of RGPP & $\mathrm{N} 36^{\circ} 40.442^{\prime}$ & W $114^{\circ} 37.412^{\prime}$ & 1.671 \\
\hline RGPP 3 & Valley of Fire, Overton, NV & $27 \mathrm{~km}$ South of RGPP & $\mathrm{N} 36^{\circ} 25.414^{\prime}$ & $\mathrm{W} 114^{\circ} 33.038^{\prime}$ & 2.206 \\
\hline RGPP 4 & Gunsight Mountain, NV & $27 \mathrm{~km}$ North h of RGPP & $\mathrm{N} 36^{\circ} 39.650^{\prime}$ & W $114^{\circ} 55.374^{\prime}$ & 2.620 \\
\hline RGPP 5 & Coyote Springs, NV & $46 \mathrm{~km}$ North of RGPP & N $36^{\circ} 57.714^{\prime}$ & W $114^{\circ} 58.476^{\prime}$ & 2.560 \\
\hline RGPP 6 & Kane Spring Wash, NV & $56 \mathrm{~km}$ North of RGPP & N $37^{\circ} 00.902^{\prime}$ & $\mathrm{W} 114^{\circ} 51.923^{\prime}$ & 2.980 \\
\hline
\end{tabular}




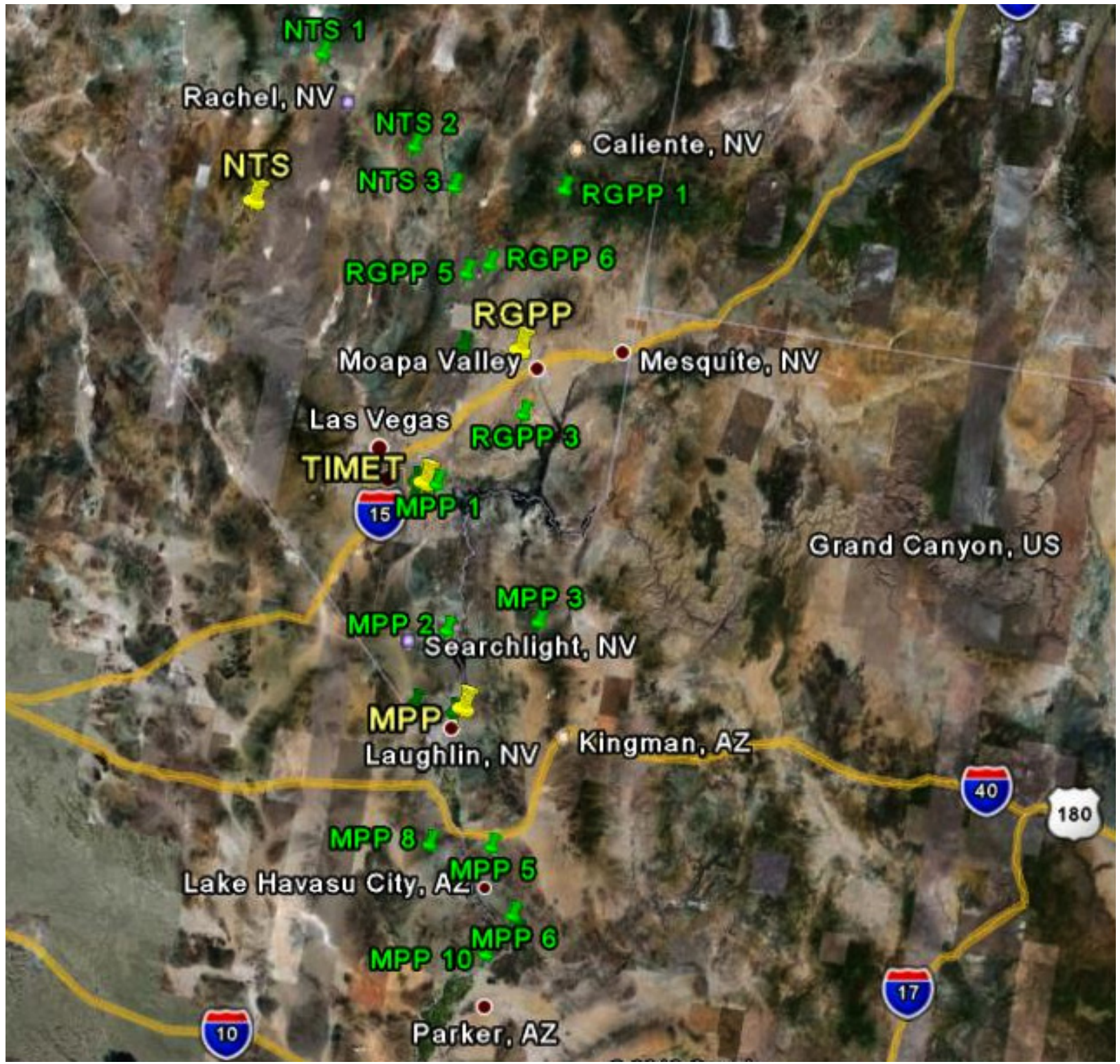

Fig. (1). Map of sampling sites.

continuously since 1985 . Varnished rocks were collected in suspected plumes of the RGPP.

The TIMET facility is located in Henderson, Nevada, in the southeast portion of Las Vegas Valley. The TIMET plant manufactures titanium industrial products, including titanium sponge, ingot, and titanium tetrachloride. The Henderson plant produces up to 13,636 tons of titanium ingots per year [19].

At each of the above locations, hand-sized samples (up to about $25 \mathrm{~cm}$ ) were collected from the ground or chipped off of the varnished surfaces of large rock formations. Majority of samples consisted of volcanic basalts, except RGPP3, which was sandstone and RGPP1 was quartzite granite. To avoid interferences from any surface deposits and vegetation, rocks with extensive tufa deposits (calcium carbonate, $\mathrm{CaCO}_{3}$ ) and lichen communities were not sampled. Three samples were taken at each location. The samples were labeled, packaged in plastic bags, and returned to the laboratory for analysis. To remove any loose particulates form the analyzed surfaces all samples were rinsed with ultra pure water, $18 \mathrm{M} \Omega-\mathrm{cm}$ or better, from a Nanopure water system (Barnstead Corporation, Dubuque, Iowa) and dried with a lint-free paper towels prior to analysis.

\subsection{Instrumentation and Data Collection}

In order to assess difference in elemental concentration between varnished and unvarnished surfaces two samples with different lithology (RGPP3 and TIMET 2) were analyzed using a LSX-213 laser ablation system (CETAC Inc., Omaha, Nebraska) interfaced with an Axiom, doublefocusing magnetic sector ICPMS which was originally manufactured by VG Elemental (now Thermo Fisher, Waltham, MA, USA). The LSX-213 employs a frequency quintupled Nd:YAG laser with a resulting wavelength of 213 $\mathrm{nm}$. The LA-ICPMS system was optimized for sensitivity (e.g. gas flows, torch position) prior to sample analysis using NIST glass SRM 614. Instrumental settings are summarized in Table 2. Briefly, the LA unit was operated at its full 
Table 2. LSX-213 Laser Ablation and Sector Field ICPMS Operating Conditions

\begin{tabular}{|c|c|}
\hline \multicolumn{2}{|c|}{ Laser Ablation Parameters } \\
\hline Laser type & Nd:YAG \\
\hline Wavelength & $213 \mathrm{~nm}$ \\
\hline Pulse Width & $5 \mathrm{~ns}$ \\
\hline Laser energy & $>4.0 \mathrm{~mJ} /$ pulse \\
\hline Pulse Rate & $20 \mathrm{~Hz}$ \\
\hline Spot size & $100 \mu \mathrm{m}$ \\
\hline Scan rate & $25 \mu \mathrm{m} \times \mathrm{s}^{-1}$ \\
\hline Energy setting & $100 \%$ \\
\hline \multicolumn{2}{|c|}{ Plasma Parameters } \\
\hline RF power & $1.2 \mathrm{~kW}$ \\
\hline Cooling gas flow & $14 \mathrm{~L} \times \min ^{-1}$ \\
\hline Auxiliary gas flow & $1.2 \mathrm{~L} \times \min ^{-1}$ \\
\hline Nebulizer gas flow & $1.2 \mathrm{~L} \times \min ^{-1}$ \\
\hline \multicolumn{2}{|c|}{ Data Acquisition } \\
\hline Masses monitored & $9,27,107,111,118,121,138,184,205,206,207,208,232,238$ \\
\hline Dwell time & $10 \mathrm{~ms}$ \\
\hline Points/peak & 1 \\
\hline Sweeps & 1 \\
\hline Runs & 10 \\
\hline Total acquisition time per run & $0.9 \mathrm{~s}$ \\
\hline \multicolumn{2}{|c|}{ Mass Spectrometer Settings } \\
\hline Mass resolution & $400(\mathrm{~m} / \Delta \mathrm{m})$ \\
\hline Ion Energy & 4970 \\
\hline Transfer 1 & 4123 \\
\hline Transfer 2 & 4200 \\
\hline $\mathrm{X}$ deflection 1 & -6 \\
\hline $\mathrm{X}$ deflection 2 & -38 \\
\hline Curve lens & 21 \\
\hline $\mathrm{X}$ lens & -1740 \\
\hline Multiplier & -2251 \\
\hline
\end{tabular}

energy setting (100\%), with a repetition rate of $20 \mathrm{~Hz}$, a spot size of $100 \mu \mathrm{m}$, and a scan rate of $25 \mu \mathrm{m} \cdot \mathrm{sec}^{-1}$, whereas the ICPMS was operated in low resolution $(\mathrm{m} / \Delta \mathrm{m} \approx 400)$ and magnetic scanning mode $(10 \mathrm{~ms}$ dwell time, 0.2 peak widths)

Thirteen isotopes $\left({ }^{9} \mathrm{Be},{ }^{107} \mathrm{Ag},{ }^{111} \mathrm{Cd},{ }^{118} \mathrm{Sn},{ }^{121} \mathrm{Sb},{ }^{184} \mathrm{~W}\right.$, $\left.{ }^{205} \mathrm{Tl},{ }^{206} \mathrm{~Pb},{ }^{207} \mathrm{~Pb},{ }^{208} \mathrm{~Pb},{ }^{209} \mathrm{Bi},{ }^{232} \mathrm{Th},{ }^{238} \mathrm{U}\right)$ were determined at low mass resolution $(\mathrm{m} / \Delta \mathrm{m} \approx 400)$. Data were collected for three ablation scans using continuous-line ablations to average the sample variability. Ablation site selection, laser focusing, and ablation parameters were monitored in real time by a camera aimed down the laser axis. Within each line scan were ten analytical runs, each consisting of $10 \mathrm{~ms}$ of signal collection per mass, plus the time it took the ICPMS to move between the masses, plus the time required for the software to "process" the data at the end of the run. Combined, the data collection and peak jumping time was relatively fast $(\sim 5 \mathrm{~s})$, corresponding to $<125 \mu \mathrm{m}$ in varnished rock distance (at a scan rate of $25 \mu \mathrm{m} \cdot \mathrm{sec}^{-1}$ ). This process was repeated three times for each rock sample (Fig. 2).
Argon gas blanks were analyzed between each sample to prevent sample cross-contamination and to assess the memory effects. All sample signals were blank corrected.

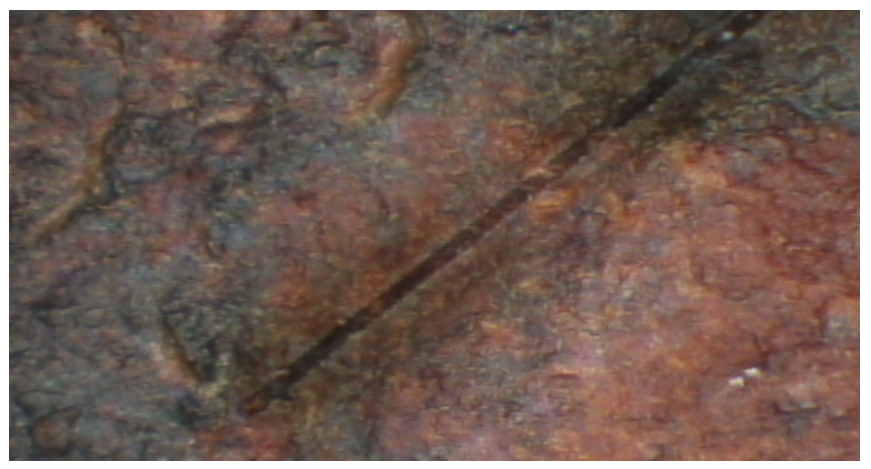

Fig. (2). Image of a varnished rock sample (RGPP 3) showing ablation track.

Bulk concentrations of elements in the varnish coatings were quantified with the LA system coupled with an ELAN 
Table 3. LSX-213 Laser Ablation and Quadrupole ICPMS Operating Conditions

\begin{tabular}{|c|c|}
\hline \multicolumn{2}{|c|}{ Laser Ablation Parameters } \\
\hline Laser type & Nd:YAG \\
\hline Wavelength & $213 \mathrm{~nm}$ \\
\hline Pulse Width & $5 \mathrm{~ns}$ \\
\hline Laser energy & $>4.0 \mathrm{~mJ} /$ pulse \\
\hline Pulse Rate & $20 \mathrm{~Hz}$ \\
\hline Spot size & $100 \mu \mathrm{m}$ \\
\hline Scan rate & $25 \mu \mathrm{m} \times \mathrm{s}^{-1}$ \\
\hline Energy setting & $100 \%$ \\
\hline \multicolumn{2}{|c|}{ Plasma Parameters } \\
\hline RF power & $1.3 \mathrm{~kW}$ \\
\hline Cooling gas flow & $15 \mathrm{~L} \times \min ^{-1}$ \\
\hline Auxiliary gas flow & $0.95 \mathrm{~L} \times \min ^{-1}$ \\
\hline Nebulizer gas flow & $1.2 \mathrm{~L} \times \min ^{-1}$ \\
\hline \multicolumn{2}{|c|}{ Data Acquisition } \\
\hline Masses monitored & $\begin{array}{c}9,51,52,59,60.65,66,88.98,107,111,118,121,133,138,197,205 \\
206,207,208,209,232,238\end{array}$ \\
\hline Scan mode & Peak hopping \\
\hline Dwell time & $100 \mathrm{~ms}$ \\
\hline Integration time & $1500 \mathrm{~ms}$ \\
\hline Sweeps/Reading & 15 \\
\hline Replicates & 3 \\
\hline Dead Time & $70 \mathrm{~ns}$ \\
\hline Total acquisition time per run & $42 \mathrm{~s}$ \\
\hline \multicolumn{2}{|c|}{ Mass Spectrometer Settings } \\
\hline Mass resolution & 0.7 \\
\hline Lens Voltage & 9 \\
\hline Analog stage voltage & -2150 \\
\hline Pulse stage voltage & 2100 \\
\hline Detector & Dual \\
\hline
\end{tabular}

6100 DRC, quadrupole ICPMS (Perkin Elmer, Concord, Ontario, Canada). Concentrations of 25 isotopes $\left({ }^{9} \mathrm{Be},{ }^{51} \mathrm{~V}\right.$, ${ }^{52} \mathrm{Cr},{ }^{59} \mathrm{Co},{ }^{60} \mathrm{Ni},{ }^{65} \mathrm{Cu},{ }^{66} \mathrm{Zn},{ }^{88} \mathrm{Sr},{ }^{98} \mathrm{Mo},{ }^{107} \mathrm{Ag},{ }^{111} \mathrm{Cd},{ }^{115} \mathrm{In}$, ${ }^{118} \mathrm{Sn},{ }^{121} \mathrm{Sb},{ }^{133} \mathrm{Cs},{ }^{138} \mathrm{Ba},{ }^{184} \mathrm{~W},{ }^{197} \mathrm{Au},{ }^{205} \mathrm{Tl},{ }^{206} \mathrm{~Pb},{ }^{207} \mathrm{~Pb}$, ${ }^{208} \mathrm{~Pb},{ }^{209} \mathrm{Bi},{ }^{232} \mathrm{Th}$, and ${ }^{238} \mathrm{U}$ ) were determined in 24 varnish samples. The same LSX-213 laser settings and optimization practices were used as in the varnish analysis with the sector field ICPMS. Instrumental settings are summarized in Table 3.

Data were collected for three ablation scans using continuous-line ablations. Within each line scan were three analytical runs, each consisting of 15 sweeps with $100 \mathrm{~ms}$ of signal collection per mass. Each analytical run lasted about $42 \mathrm{~s}$, corresponding to a total distance of $1.05 \mathrm{~mm}$ in varnished rock distance (at a scan rate of $25 \mu \mathrm{m} \cdot \mathrm{sec}^{-1}$ ). Overall, about $3.15 \mathrm{~mm}$ of the rock surface were ablated (3 runs). This process was repeated three times for each rock sample.

\section{RESULTS AND DISCUSSION}

\subsection{Calibration and Detection Limits}

The ICPMS instruments were calibrated with a set of multi-element NIST SRM glass standards (61X series). These standards have been well characterized in LA-ICPMS studies and provide reliable calibrations for analysis of many geological materials $[12,20]$. The certified values for the SRM were used; and when that information was unavailable, consensus values were used [20, 21]. Aluminum-27 was used as an internal standard (IS) for sector field ICPMS analyses.

The sector field ICPMS calibration curves yielded good linearity for all elements. Correlation coefficients for concentration versus instrumental response in counts-persecond (cps) were $\geq 0.999$ for eight elements (Be, $\mathrm{Ag}, \mathrm{Sn}$, $\mathrm{Sb}, \mathrm{Ba}, \mathrm{W}, \mathrm{Tl}$, and $\mathrm{U}$ ); for $\mathrm{Cd}$ (only one standard value was 
available) and Th were 1.000; and for $\mathrm{Pb} 0.996$, respectively. To examine the accuracy of the calibration, elemental concentrations were obtained for glass SRM 612 using the standard as an unknown. Excellent agreement with certified or consensus values was obtained with only the results for $\mathrm{Pb}$ $(131 \%)$ and $U(78 \%)$ falling outside of the range of $80-$ $120 \%$.

Precision of the analytical method was verified by calculating a relative percent difference (RPD) between duplicate measurements of SRM 612 (Table 4). Most of the elements have RPDs within the limit $(<20 \%)$, except for W $(25 \%), \mathrm{Pb}(32 \%)$ and $\mathrm{U}(22 \%)$. Method detection limits (MDLs) were calculated based on replicate measurements $(\mathrm{n}=90)$ of argon gas blanks and the slope of the calibration curve $(3 \sigma)$. The MDLs range from $0.001 \mu \mathrm{g} \cdot \mathrm{g}^{-1}$ for $\mathrm{Be}, \mathrm{U}$, and Th to $0.50 \mu \mathrm{g} \cdot \mathrm{g}^{-1}$ for Ag (Table 4).

For quadrupole ICPMS calibrations correlation coefficients were $\geq 0.995$ for 21 of the 23 elements (Bi and Au had only one standard value available). Again, the accuracy and precision of the method was verified with SRM 612. The elemental recoveries had an excellent agreement with certified or consensus values, with only two results falling outside of the range of $80-120 \%$ : $\mathrm{Zn}(69 \%)$ and $\mathrm{Sr}(77 \%)$ (no values were available for $\mathrm{Bi}, \mathrm{W}, \mathrm{In}$, and $\mathrm{Cd}$ ). The majority of the elements have RPDs within the acceptable limit $(<20 \%)$, except for $\mathrm{Cd}$ $(30 \%)$ and $\mathrm{Zn}(21 \%)$ (Table 5). MDLs were calculated based on replicate measurements $(n=42)$ of argon gas blanks and the slope of the calibration curve $(3 \sigma)$. The MDLs ranged from $0.001 \mu \mathrm{g} \cdot \mathrm{g}^{-1}$ for Bi to $47.6 \mu \mathrm{g} \cdot \mathrm{g}^{-1}$ for Sr (Table 5).

\subsection{Magnetic Sector ICPMS Sample Data}

Both varnish samples have varied concentrations of trace elements (Table 6). Barium (271 to $1830 \mu \mathrm{g} \cdot \mathrm{g}^{-1}$ ) and $\mathrm{Pb}$ (34.2 to $814 \mu \mathrm{g} \cdot \mathrm{g}^{-1}$ ) are by far the most abundant, and Th is also highly enriched (12.4 to $\left.15.4 \mu \mathrm{g} \cdot \mathrm{g}^{-1}\right)$ in both samples. The varnished surface of RGPP 3 has trace element concentrations that range from $1270 \mu \mathrm{g} \cdot \mathrm{g}^{-1}$ for $\mathrm{Ba}$ to 0.890 $\mu \mathrm{g} \cdot \mathrm{g}^{-1}$ for $\mathrm{Ag}$, with elements listed (in order of abundance): $\mathrm{Ba}>\mathrm{Pb}>\mathrm{Th}>\mathrm{Cd}>\mathrm{W}>\mathrm{Tl}>\mathrm{Be}>\mathrm{Sb}>\mathrm{Sn} \approx \mathrm{U}>\mathrm{Ag}$. The varnished surface of TIMET 2 has trace element concentrations that range from $1830 \mu \mathrm{g} \cdot \mathrm{g}^{-1}$ for $\mathrm{Ba}$ to 1.85 $\mu \mathrm{g} \cdot \mathrm{g}^{-1}$ for $\mathrm{U}$, with elements listed (in order of abundance): $\mathrm{Ba}$ $>\mathrm{Pb}>\mathrm{Tl}>\mathrm{Th}>\mathrm{Sn} \approx \mathrm{Cd} \approx \mathrm{Sb}>\mathrm{W}>\mathrm{Ag}>\mathrm{Be}>\mathrm{U}$.

To statistically evaluate the difference between varnished and substrate rock (unvarnished) surfaces, the null hypothesis, that "the means of the results from analysis of both surfaces are equal", was tested [22]. The comparison of the experimental $t$ values with the critical values of $t(\mathrm{P}=$ 0.05 ) shows significant difference in the concentrations of seven elements $(\mathrm{Be}, \mathrm{Cd}, \mathrm{Ba}, \mathrm{W}, \mathrm{Tl}, \mathrm{Pb}$, and $\mathrm{Th})$ in sample RGPP 3. There is no significant difference in the concentrations of $\mathrm{Ag}, \mathrm{Sn}, \mathrm{Sb}$, and $\mathrm{U}$.

Eight elements $(\mathrm{Cd}>\mathrm{Th}>\mathrm{Ba}>\mathrm{Pb}>\mathrm{W}>\mathrm{Be}>\mathrm{Tl}>\mathrm{U})$ have higher concentrations in the varnished surface than in the unvarnished substrate rock. In contrast, concentrations of $\mathrm{Ag}, \mathrm{Sn}$, and $\mathrm{Sb}$ were higher in the unvarnished surface of sample RGPP3. This could be caused by the limited sorption of these low solubility elements into the varnish films. Tebo et al. [10] reported that $\mathrm{Mn}$ oxide minerals can adsorb or incorporate from solutions substantial amounts of $\mathrm{Ca}, \mathrm{Fe}$, $\mathrm{Co}, \mathrm{Ni}, \mathrm{Cu}, \mathrm{Zn}, \mathrm{As}, \mathrm{Se}, \mathrm{Cd}, \mathrm{Sn}, \mathrm{Hg}, \mathrm{Pb}, \mathrm{Po}, \mathrm{Ra}, \mathrm{Th}, \mathrm{U}$, and $\mathrm{Pu}$. However, sorption, ion exchange, and precipitation of metals by Mn oxides are affected by multiple factors [10]. Solubility in rain or fog droplets during wet deposition is a main factor that influences enrichment of the metal in the varnish coatings [11].

The comparison of the experimental $t$ values with the critical values of $t(\mathrm{P}=0.05)$ demonstrate significant differences in the concentrations of nine elements $(\mathrm{Cd}, \mathrm{Sn}$, $\mathrm{Sb}, \mathrm{Ba}, \mathrm{W}, \mathrm{Tl}, \mathrm{Pb}, \mathrm{Th}$, and $\mathrm{U}$ ) for sample TIMET 2. There is no significant difference in the concentrations of $\mathrm{Be}$ and $\mathrm{Ag}$. Trace element concentrations are consistently higher in the

Table 4. Sector Field LA-ICPMS Results for Duplicate Analyses of Glass Reference Material NIST SRM 612 Using Three Glass Reference Materials NIST SRM 616, 614, and 612 for Calibration (Concentrations Given in $\mu \mathrm{g} \cdot \mathrm{g}^{-1}$ )

\begin{tabular}{|c|c|c|c|c|c|c|c|c|}
\hline \multirow{2}{*}{ Element } & \multirow{2}{*}{ MDL } & \multicolumn{3}{|c|}{ SRM 612 } & \multicolumn{3}{c|}{ SRM 612 } \\
\cline { 3 - 9 } & & Found & $\begin{array}{c}\text { Certified or Ref. } \\
\text { Value }\end{array}$ & \% Rec. & Found & \multicolumn{2}{c|}{$\begin{array}{c}\text { Certified or Ref. } \\
\text { Value }\end{array}$} & \% Rec. \\
\hline \hline $\mathrm{Be}$ & 0.001 & $33.5 \pm 2.2$ & 37.15 & 90 & $23.5 \pm 1.5$ & 37.15 & 90 & 0 \\
\hline $\mathrm{Ag}$ & 0.501 & $21.9 \pm 1.6$ & $22.0 \pm 0.3$ & 100 & $22.1 \pm 2.2$ & $22.0 \pm 0.3$ & 101 & 1 \\
\hline $\mathrm{Cd}$ & 0.468 & $11.2 \pm 0.7$ & $\mathrm{NA}$ & $\mathrm{NA}$ & $10.9 \pm 0.9$ & NA & NA & 3 \\
\hline $\mathrm{Sn}$ & 0.344 & $35.4 \pm 2.1$ & 38.98 & 91 & $33.9 \pm 3.5$ & 38.98 & 87 & 4 \\
\hline $\mathrm{Sb}$ & 0.140 & $33.7 \pm 2.6$ & 36.22 & 93 & $31.1 \pm 3.5$ & 36.22 & 86 & 8 \\
\hline $\mathrm{Ba}$ & 0.365 & $40.4 \pm 2.6$ & 41 & 99 & $40.4 \pm 4.5$ & 31 & 99 \\
\hline $\mathrm{W}$ & 0.009 & $43.7 \pm 2.2$ & $\mathrm{NA}$ & $\mathrm{NA}$ & $34.0 \pm 5.9$ & NA & NA & 25 \\
\hline $\mathrm{Tl}$ & 0.086 & $14.3 \pm 1.3$ & $15.7 \pm 0.3$ & 91 & $15.9 \pm 1.2$ & $15.7 \pm 0.3$ & 101 & 10 \\
\hline $\mathrm{Pb}$ & 0.034 & $36.7 \pm 2.3$ & $38.57 \pm 0.2$ & 95 & $50.6 \pm 18.3$ & $38.57 \pm 0.2$ & 131 & 32 \\
\hline $\mathrm{Th}$ & 0.001 & $38.8 \pm 1.3$ & $37.79 \pm 0.08$ & 103 & $32.0 \pm 5.3$ & $37.79 \pm 0.08$ & 85 & 19 \\
\hline $\mathrm{U}$ & 0.001 & $36.5 \pm 18.6$ & $37.38 \pm 0.08$ & 98 & $29.3 \pm 5.9$ & $37.38 \pm 0.08$ & 78 & 22 \\
\hline
\end{tabular}


Table 5. Quadrupole LA-ICPMS Results for Duplicate Analysis of Glass Reference Material NIST SRM 612 Using Three Glass Reference Materials NIST SRM 616, 614, and 612 for Calibration. Concentrations are Reported in $\mu \mathrm{g} \cdot \mathrm{g}^{-1}$

\begin{tabular}{|c|c|c|c|c|c|c|c|}
\hline \multirow{2}{*}{ Element } & \multirow{2}{*}{ MDL } & \multicolumn{5}{|c|}{ SRM 612} & \multirow{2}{*}{ RPD } \\
\hline & & Found & Found & Certified or ref. Value & \% Rec. & \% Rec. & \\
\hline $\mathrm{Be}$ & 0.281 & $31.6 \pm 1.8$ & $35.0 \pm 3.6$ & 37.15 & 85 & 94 & 10 \\
\hline $\mathrm{V}$ & 16.3 & $32.7 \pm 3.8$ & $37.2 \pm 4.3$ & 38.76 & 84 & 96 & 13 \\
\hline $\mathrm{Cr}$ & 4.65 & $32.3 \pm 3.7$ & $38.1 \pm 3.8$ & 39.59 & 82 & 96 & 17 \\
\hline Co & 1.53 & $29.7 \pm 3.0$ & $32.9 \pm 3.6$ & $35.5 \pm 1.2$ & 81 & 93 & 14 \\
\hline $\mathrm{Ni}$ & 1.50 & $31.1 \pm 3.1$ & $34.3 \pm 4.5$ & $38.8 \pm 0.2$ & 80 & 88 & 10 \\
\hline $\mathrm{Cu}$ & 5.16 & $30.6 \pm 3.5$ & $33.5 \pm 3.2$ & $37.7 \pm 0.9$ & 81 & 89 & 9 \\
\hline $\mathrm{Zn}$ & 27.5 & $26.2 \pm 9.5$ & $32.4 \pm 6.4$ & 37.96 & 69 & 85 & 21 \\
\hline $\mathrm{Sr}$ & 47.6 & $60.2 \pm 9.9$ & $70.2 \pm 9.7$ & $78.4 \pm 0.2$ & 77 & 90 & 15 \\
\hline Mo & 0.592 & $30.5 \pm 2.5$ & $33.1 \pm 2.6$ & 35.99 & 85 & 92 & 8 \\
\hline $\mathrm{Ag}$ & 0.061 & $24.0 \pm 3.6$ & $24.0 \pm 2.7$ & $22.0 \pm 0.3$ & 109 & 109 & 0 \\
\hline $\mathrm{Cd}$ & 0.044 & $20.0 \pm 4.0$ & $14.8 \pm 1.7$ & NA & NA & NA & 30 \\
\hline In & 0.009 & $30.5 \pm 3.8$ & $28.1 \pm 2.5$ & NA & NA & NA & 8 \\
\hline $\mathrm{Sn}$ & 2.29 & $31.4 \pm 3.3$ & $32.8 \pm 2.5$ & 38.98 & 87 & 90 & 4 \\
\hline $\mathrm{Sb}$ & 0.708 & $31.6 \pm 4.7$ & $29.3 \pm 2.7$ & 36.22 & 87 & 81 & 8 \\
\hline Cs & 0.916 & $34.7 \pm 3.6$ & $38.0 \pm 3.3$ & 41.51 & 84 & 92 & 9 \\
\hline $\mathrm{Ba}$ & 2.24 & $33.9 \pm 3.4$ & $40.6 \pm 3.3$ & 41 & 83 & 99 & 18 \\
\hline W & 0.03 & $27.0 \pm 2.5$ & $27.9 \pm 2.1$ & NA & NA & NA & 3 \\
\hline $\mathrm{Au}$ & 0.003 & $5.6 \pm 0.6$ & $5.7 \pm 0.5$ & 5 & 113 & 113 & 0 \\
\hline $\mathrm{Tl}$ & 2.35 & $16.2 \pm 2.4$ & $14.5 \pm 1.9$ & $15,7 \pm 0.3$ & 103 & 92 & 12 \\
\hline $\mathrm{Pb}$ & 2.61 & $32.8 \pm 6.0$ & $34.7 \pm 2.4$ & $38.57 \pm 0.2$ & 85 & 89 & 5 \\
\hline $\mathrm{Bi}$ & 0.001 & $3.0 \pm 0.5$ & $2.5 \pm 0.3$ & NA & NA & NA & 16 \\
\hline Th & 0.344 & $32.7 \pm 3.5$ & $33.7 \pm 2.7$ & $37.79 \pm 0.08$ & 87 & 89 & 3 \\
\hline $\mathrm{U}$ & 0.246 & $31.7 \pm 2.8$ & $34.2 \pm 2.5$ & $37.38 \pm 0.08$ & 85 & 91 & 8 \\
\hline
\end{tabular}

The "informational" values do not have uncertainties associated with them. Found values are \pm 1 SD. Certified or consensus values are $\pm 95 \%$ confidence limit NA $=$ Not Available.

varnished surface. The elemental concentration ratios in descending order are: $\mathrm{Tl}>\mathrm{Cd}>\mathrm{Pb}>\mathrm{Sn}>\mathrm{Sb}>\mathrm{W}>\mathrm{Ba}>\mathrm{U}$ $>\mathrm{Th}>\mathrm{Ag}>\mathrm{Be}$.

\subsection{Quadrupole ICPMS Sample Data}

Analytical results for the quadrupole ICPMS analyses of desert varnish samples are found in Table 7. Each result represents the average of 9 individual analyses (3 lines, 3 replicates), and was obtained using continuous-line ablations. Only varnished rock surfaces were analyzed. The irregularities of varnish coatings may account for variations in $\%$ RSD of the means of the individual results.

As previously observed, $\mathrm{Ba}$ (408 to $38600 \mu \mathrm{g} \cdot \mathrm{g}^{-1}$ ) and $\mathrm{Pb}$

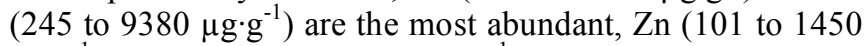
$\left.\mu \mathrm{g} \cdot \mathrm{g}^{-1}\right)$ and $\mathrm{Sr}\left(78.9\right.$ to $\left.3630 \mu \mathrm{g} \cdot \mathrm{g}^{-1}\right)$ are also enriched in all samples. Some samples (MPP 9, RGPP 4, RGPP 5, and RGPP 6) have very high $\mathrm{Pb}$ signals and the alternate lines were analyzed. Indium is not detected in samples TIMET 2, TIMET 3, MPP 1, MPP 4, MPP 8, and RGPP 3; and Sn is not detected in samples MPP 7, MPP 8, MPP 9, and RGPP 4.
Sample NTS 1 has very high concentrations of $\mathrm{V}(800 \mu \mathrm{g} \cdot \mathrm{g}$ $\left.{ }^{1}\right)$, Mo $\left(614 \mu \mathrm{g} \cdot \mathrm{g}^{-1}\right)$, and Sb $\left(2070 \mu \mathrm{g} \cdot \mathrm{g}^{-1}\right)$. The concentration of $U\left(50.3 \mu \mathrm{g} \cdot \mathrm{g}^{-1}\right)$ in NTS 1 has the highest value for $U$ in any of the samples. Figs. (3-7) show selected elemental abundances for desert varnish in vicinity of each point source normalized to estimates of the average composition of the UCC [23].

There is a noticeable difference in the chemical composition of sample NTS 1, compared to NTS 2 and NTS 3 (Fig. 3). The NTS 1 sample shows enrichment of $\mathrm{Sb}>\mathrm{Mo}$ $>\mathrm{Cd}>\mathrm{Pb}>\mathrm{U}>\mathrm{W}>\mathrm{V}>\mathrm{Be}>\mathrm{In}>\mathrm{Zn}>\mathrm{Th}>\mathrm{Cr}>\mathrm{Sr}$; where $\mathrm{Sb}$ and Mo are extremely enriched at 2760 and 1020 times more than in the UCC, respectively. Cadmium and $\mathrm{Pb}$ are also highly enriched, about 62 and 22 times more than in the UCC. On the other hand, $\mathrm{Cu}, \mathrm{Tl}, \mathrm{Ba}, \mathrm{Sn}, \mathrm{Bi}, \mathrm{Ni}, \mathrm{Co}$, and Cs are depleted. The NTS 1 sample also has a very low ratio of $\mathrm{Th} / \mathrm{U}=0.67$, while the average UCC values range from 3.7 to 4.0 [23]. The low ratio of $\mathrm{Th} / \mathrm{U}$ could possibly be attributed to the activities at the NTS, since the sampling site is located next to the NTS. 
Table 6. Concentrations of Elements $\left(\mu \mathrm{g} \cdot \mathrm{g}^{-1}\right)$ in Desert Varnish Using Sector field LA-ICPMS

\begin{tabular}{|c|c|c|c|c|c|c|}
\hline Sample & Analyte & Line 1 & Line 2 & Line 3 & Mean & RSD (\%) \\
\hline $\begin{array}{c}\text { RGPP } 3 \\
\text { Varnished }\end{array}$ & $\begin{array}{l}\mathrm{Be} \\
\mathrm{Ag} \\
\mathrm{Cd} \\
\mathrm{Sn} \\
\mathrm{Sb} \\
\mathrm{Ba} \\
\mathrm{W} \\
\mathrm{Tl} \\
\mathrm{Pb} \\
\mathrm{Th} \\
\mathrm{U}\end{array}$ & $\begin{array}{c}2.46 \pm 1.29 \\
0.80 \pm 0,13 \\
7.03 \pm 4.01 \\
1.00 \pm 0.30 \\
1.65 \pm 0.63 \\
1252 \pm 595 \\
4.02 \pm 1.49 \\
2.83 \pm 1.51 \\
268 \pm 52 \\
13.8 \pm 7.1 \\
0.89 \pm 0.39\end{array}$ & $\begin{array}{c}2.94 \pm 1.51 \\
0.78 \pm 0.25 \\
9.64 \pm 6.52 \\
1.11 \pm 0.37 \\
1.74 \pm 0.58 \\
1285 \pm 601 \\
3.83 \pm 0.98 \\
2.81 \pm 1.23 \\
251 \pm 53 \\
14.7 \pm 6.1 \\
1.00 \pm 0.36\end{array}$ & $\begin{array}{c}2.76 \pm 1.73 \\
1.07 \pm 0.56 \\
7.03 \pm 3.83 \\
1.28 \pm 0.40 \\
1.70 \pm 0.60 \\
\mathrm{NA} \\
5.04 \pm 2.38 \\
2,47 \pm 1.03 \\
270 \pm 103 \\
17.6 \pm 9.8 \\
1.25 \pm 0.61\end{array}$ & $\begin{array}{c}2.72 \pm 0.24 \\
0.89 \pm 0.16 \\
7.99 \pm 1.51 \\
1.13 \pm 0.14 \\
1.70 \pm 0.05 \\
1269 \pm 23 \\
4.30 \pm 0.66 \\
2,70 \pm 0.20 \\
263 \pm 10 \\
15.4 \pm 2.0 \\
1.05 \pm 0.18\end{array}$ & $\begin{array}{c}9 \\
18 \\
19 \\
13 \\
3 \\
2 \\
15 \\
8 \\
4 \\
13 \\
18\end{array}$ \\
\hline $\begin{array}{c}\text { RGPP } 3 \\
\text { Unvarnished }\end{array}$ & $\begin{array}{l}\mathrm{Be} \\
\mathrm{Ag} \\
\mathrm{Cd} \\
\mathrm{Sn} \\
\mathrm{Sb} \\
\mathrm{Ba} \\
\mathrm{W} \\
\mathrm{Tl} \\
\mathrm{Pb} \\
\mathrm{Th} \\
\mathrm{U}\end{array}$ & $\begin{array}{c}1.06 \pm 0.35 \\
3.67 \pm 8.37 \\
0.51 \pm 0.14 \\
2.36 \pm 0.87 \\
1.88 \pm 0.40 \\
251 \pm 311 \\
1.13 \pm 0.57 \\
1.17 \pm 0.52 \\
50.1 \pm 13.3 \\
2.09 \pm 0.50 \\
0.57 \pm 0.26\end{array}$ & $\begin{array}{c}1.38 \pm 0.56 \\
\text { NA } \\
0.64 \pm 0.17 \\
2.61 \pm 0.53 \\
2.03 \pm 0.35 \\
265 \pm 162 \\
1.05 \pm 0.17 \\
1.89 \pm 0.96 \\
61.4 \pm 9.2 \\
2.45 \pm 0.54 \\
0.63 \pm 0.17\end{array}$ & $\begin{array}{c}1.86 \pm 0.59 \\
4.20 \pm 8.27 \\
1.08 \pm 0.33 \\
3.57 \pm 0.78 \\
2.69 \pm 0.70 \\
2971 \pm 51 \\
1.45 \pm 0.43 \\
1.79 \pm 0.53 \\
72.8 \pm 12.8 \\
3.91 \pm 0.99 \\
1.26 \pm 0.32\end{array}$ & $\begin{array}{c}1.46 \pm 0.40 \\
3,93 \pm 0.37 \\
0.74 \pm 0.30 \\
2.85 \pm 0.64 \\
2.20 \pm 0.43 \\
271 \pm 24 \\
1.21 \pm 0.21 \\
1.61 \pm 0.39 \\
61.4 \pm 11.4 \\
2.81 \pm 0.96 \\
0.82 \pm 0.38\end{array}$ & $\begin{array}{c}28 \\
10 \\
40 \\
22 \\
20 \\
9 \\
18 \\
24 \\
19 \\
34 \\
47\end{array}$ \\
\hline $\begin{array}{l}\text { TIMET } 2 \\
\text { Varnished }\end{array}$ & $\begin{array}{l}\mathrm{Be} \\
\mathrm{Ag} \\
\mathrm{Cd} \\
\mathrm{Sn} \\
\mathrm{Sb} \\
\mathrm{Ba} \\
\mathrm{W} \\
\mathrm{Tl} \\
\mathrm{Pb} \\
\mathrm{Th} \\
\mathrm{U}\end{array}$ & $\begin{array}{c}1.33 \pm 0.71 \\
3.77 \pm 1.28 \\
7.97 \pm 2.75 \\
7.42 \pm 1.48 \\
9.38 \pm 4.09 \\
1606 \pm 525 \\
6.85 \pm 2.50 \\
25.2 \pm 8.9 \\
771 \pm 314 \\
9.83 \pm 5.42 \\
1.21 \pm 0.64\end{array}$ & $\begin{array}{c}3.29 \pm 0.64 \\
\text { NA } \\
9.30 \pm 3.27 \\
9.42 \pm 2.95 \\
6.59 \pm 1.50 \\
2245 \pm 399 \\
6.77 \pm 1.80 \\
29.2 \pm 9.0 \\
1072 \pm 581 \\
17.9 \pm 4.8 \\
2.23 \pm 0.67\end{array}$ & $\begin{array}{c}2.27 \pm 0.62 \\
6.02 \pm 0.46 \\
5.66 \pm 0.92 \\
6.98 \pm 1.23 \\
6.38 \pm 3.09 \\
1633 \pm 291 \\
5.65 \pm 2.78 \\
21.6 \pm 6.5 \\
599 \pm 407 \\
17.2 \pm 7.1 \\
2.11 \pm 0.80\end{array}$ & $\begin{array}{c}2.30 \pm 0.98 \\
4.85 \pm 1.59 \\
7.64 \pm 1.84 \\
7.94 \pm 1.30 \\
7.45 \pm 1.68 \\
1828 \pm 361 \\
6.42 \pm 0.67 \\
25.3 \pm 3.7 \\
814 \pm 239 \\
15.0 \pm 4.5 \\
1.85 \pm 0.56\end{array}$ & $\begin{array}{l}43 \\
33 \\
24 \\
16 \\
23 \\
20 \\
11 \\
15 \\
29 \\
30 \\
30\end{array}$ \\
\hline $\begin{array}{c}\text { TIMET } 2 \\
\text { Unvarnished }\end{array}$ & $\begin{array}{l}\mathrm{Be} \\
\mathrm{Ag} \\
\mathrm{Cd} \\
\mathrm{Sn} \\
\mathrm{Sb} \\
\mathrm{Ba} \\
\mathrm{W} \\
\mathrm{Tl} \\
\mathrm{Pb} \\
\mathrm{Th} \\
\mathrm{U}\end{array}$ & $\begin{array}{c}1.58 \pm 0.71 \\
2.75 \pm 1.15 \\
0.17 \pm 0.07 \\
0.93 \pm 0.18 \\
0.82 \pm 0.19 \\
502 \pm 171 \\
0.86 \pm 0.27 \\
0.55 \pm 0.18 \\
23.8 \pm 8.9 \\
5.51 \pm 2.72 \\
0.55 \pm 0.26\end{array}$ & $\begin{aligned} 1.54 & \pm 0.64 \\
2.57 & \pm 1.40 \\
0.17 & \pm 0.06 \\
0.65 & \pm 0.20 \\
0.84 & \pm 0.33 \\
566 & \pm 213 \\
0.92 & \pm 0.62 \\
0.43 & \pm 0.21 \\
\mathrm{NA} & \\
5.68 & \pm 3.63 \\
0.61 & \pm 0,37\end{aligned}$ & $\begin{array}{c}1.51 \pm 0.42 \\
\text { NA } \\
0.20 \pm 0.05 \\
0.86 \pm 0,35 \\
0.99 \pm 0.60 \\
527 \pm 317 \\
1.17 \pm 1.06 \\
0.57 \pm 0.36 \\
44.7 \pm 39 \\
5.98 \pm 4.16 \\
0.72 \pm 0.57\end{array}$ & $\begin{array}{c}1.55 \pm 0.04 \\
2.66 \pm 0.13 \\
0.18 \pm 0.02 \\
0.81 \pm 0.14 \\
0.88 \pm 0.09 \\
532 \pm 32 \\
0.99 \pm 0.16 \\
0.52 \pm 0.08 \\
34.2 \pm 14.8 \\
5.72 \pm 0.24 \\
0.63 \pm 0.08\end{array}$ & $\begin{array}{c}3 \\
5 \\
10 \\
18 \\
10 \\
6 \\
17 \\
15 \\
43 \\
4 \\
13\end{array}$ \\
\hline
\end{tabular}


Table 7A. Quadrupole LA-ICPMS Data from Desert Varnish Samples

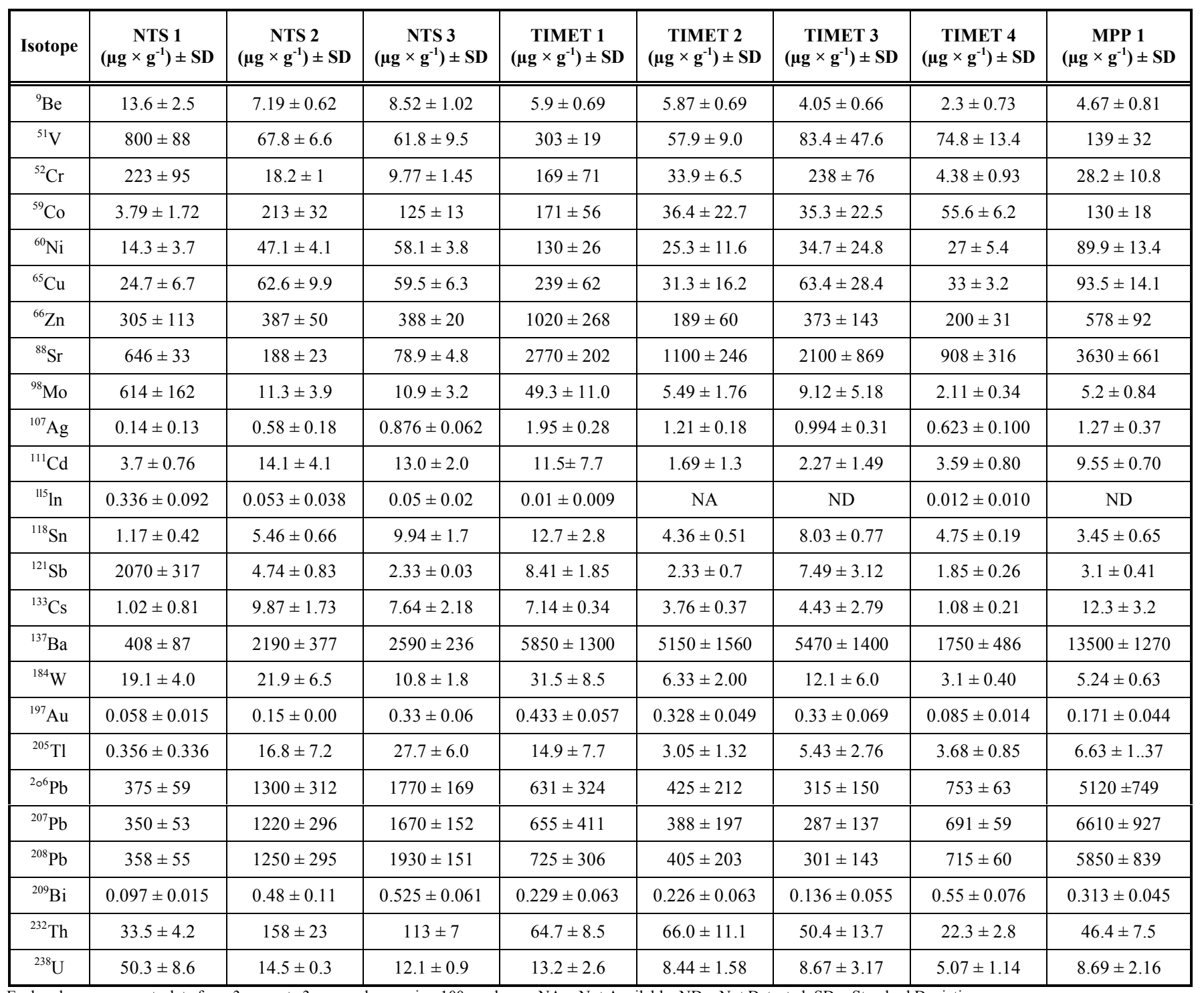

Each column represents data from 3 separate 3-run analyses using $100 \mu \mathrm{m}$ beam; NA $=$ Not Available; ND $=$ Not Detected, SD $=$ Standard Deviation.

Table 7B. Quadrupole LA-ICPMS Data from Desert Varnish Samples

\begin{tabular}{|c|c|c|c|c|c|c|c|c|}
\hline Isotope & $\begin{array}{c}\text { MPP 2 } \\
\left(\mu \mathrm{g} \times \mathrm{g}^{-1}\right) \pm \mathrm{SD}\end{array}$ & $\begin{array}{c}\text { MPP 3 } \\
\left(\mu \mathrm{g} \times \mathrm{g}^{-1}\right) \pm \mathrm{SD}\end{array}$ & $\begin{array}{c}\text { MPP 4 } \\
\left(\mu \mathrm{g} \times \mathrm{g}^{-1}\right) \pm \mathrm{SD}\end{array}$ & $\begin{array}{c}\text { MPP 5 } \\
\left(\mu \mathrm{g} \times \mathrm{g}^{-1}\right) \pm \text { SD }\end{array}$ & $\begin{array}{c}\text { MPP 6 } \\
\left(\mu \mathrm{g} \times \mathrm{g}^{-1}\right) \pm \mathrm{SD}\end{array}$ & $\begin{array}{c}\text { MPP 7 } \\
\left(\mu \mathrm{g} \times \mathrm{g}^{-1}\right) \pm \mathrm{SD}\end{array}$ & $\begin{array}{c}\text { MPP 8 } \\
\left(\mu \mathrm{g} \times \mathrm{g}^{-1}\right) \pm \mathrm{SD}\end{array}$ & $\begin{array}{c}\text { MPP 9 } \\
\left(\mu \mathrm{g} \times \mathrm{g}^{-1}\right) \pm \mathrm{SD}\end{array}$ \\
\hline${ }^{9} \mathrm{Be}$ & $5.14 \pm 0.92$ & $17.6 \pm 3.3$ & $1.96 \pm 0.53$ & $5.33 \pm 0.79$ & $9.16 \pm 1.75$ & $5.11 \pm 1.30$ & $11.2 \pm 3.5$ & $2.93 \pm 0.68$ \\
\hline${ }^{51} \mathrm{~V}$ & $138 \pm 40$ & $176 \pm 22$ & $135 \pm 26$ & $152 \pm 38$ & $154 \pm 27$ & $241 \pm 84$ & $25.8 \pm 13.3$ & $76.7 \pm 14.5$ \\
\hline${ }^{52} \mathrm{Cr}$ & $83.4 \pm 21.7$ & $46.6 \pm 15.6$ & $112 \pm 58$ & $30.0 \pm 8.6$ & $12.8 \pm 3.7$ & $21 \pm 8.8$ & ND & $16.8 \pm 6.4$ \\
\hline${ }^{59} \mathrm{Co}$ & $309 \pm 108$ & $457 \pm 118$ & $94.9 \pm 5.8$ & $366 \pm 26$ & $110 \pm 16$ & $345 \pm 177$ & $135 \pm 81$ & $57.9 \pm 11.4$ \\
\hline${ }^{60} \mathrm{Ni}$ & $132 \pm 66$ & $160 \pm 40$ & $98.4 \pm 12.1$ & $60.4 \pm 14.7$ & $52.5 \pm 9.2$ & $336 \pm 86$ & $71.3 \pm 29.2$ & $60.3 \pm 12.3$ \\
\hline${ }^{65} \mathrm{Cu}$ & $232 \pm 129$ & $238 \pm 82$ & $81.9 \pm 24.3$ & $85.1 \pm 31.7$ & $157 \pm 12$ & NA & NA & NA \\
\hline${ }^{66} \mathrm{Zn}$ & $812 \pm 406$ & $523 \pm 162$ & $182 \pm 38$ & $365 \pm 75$ & $1450 \pm 39$ & $299 \pm 136$ & $101 \pm 73$ & $213 \pm 34$ \\
\hline${ }^{88} \mathrm{Sr}$ & $1420 \pm 478$ & $1230 \pm \quad 246$ & $1050 \pm 504$ & $424 \pm 141$ & $350 \pm 169$ & $808 \pm 374$ & $211 \pm 22$ & $340 \pm 210$ \\
\hline${ }^{98} \mathrm{Mo}$ & $17.5 \pm 2.8$ & $13.8 \pm 1.7$ & $1.52 \pm 1.12$ & $6.45 \pm 1.31$ & $4.29 \pm 2.06$ & $3.48 \pm 1,61$ & $0.965 \pm 0.528$ & $1.66 \pm 0.32$ \\
\hline${ }^{107} \mathrm{Ag}$ & $2.84 \pm 1.41$ & $1.87 \pm 0.28$ & $0.279 \pm 0.110$ & $1.33 \pm 0.15$ & $0.143 \pm 0.041$ & $0.360 \pm 0.225$ & $0.974 \pm 0.156$ & $0.333 \pm 0.039$ \\
\hline
\end{tabular}


(Table 7B) contd.....

\begin{tabular}{|c|c|c|c|c|c|c|c|c|}
\hline Isotope & $\begin{array}{c}\text { MPP 2 } \\
\left(\mu \mathrm{g} \times \mathrm{g}^{-1}\right) \pm \mathrm{SD}\end{array}$ & $\begin{array}{c}\text { MPP 3 } \\
\left(\mu \mathrm{g} \times \mathrm{g}^{-1}\right) \pm \mathrm{SD}\end{array}$ & $\begin{array}{c}\text { MPP 4 } \\
\left(\mu \mathrm{g} \times \mathrm{g}^{-1}\right) \pm \mathrm{SD}\end{array}$ & $\begin{array}{c}\text { MPP 5 } \\
\left(\mu \mathrm{g} \times \mathrm{g}^{-1}\right) \pm \mathrm{SD}\end{array}$ & $\begin{array}{c}\text { MPP } 6 \\
\left(\mu \mathrm{g} \times \mathrm{g}^{-1}\right) \pm \mathrm{SD}\end{array}$ & $\begin{array}{c}\text { MPP } 7 \\
\left(\mu \mathrm{g} \times \mathrm{g}^{-1}\right) \pm \mathrm{SD}\end{array}$ & $\begin{array}{c}\text { MPP 8 } \\
\left(\mu \mathrm{g} \times \mathrm{g}^{-1}\right) \pm \mathrm{SD}\end{array}$ & $\begin{array}{c}\text { MPP 9 } \\
\left(\mu \mathrm{g} \times \mathrm{g}^{-1}\right) \pm \mathrm{SD}\end{array}$ \\
\hline${ }^{111} \mathrm{Cd}$ & $27.9 \pm 20.0$ & $16.2 \pm 7.5$ & $4.62 \pm 2.73$ & $9.50 \pm 1.09$ & $2.35 \pm 0.95$ & $6.94 \pm 6.74$ & $7.18 \pm 7.12$ & $7.55 \pm 1.54$ \\
\hline${ }^{115} \mathrm{In}$ & $0.131 \pm 0.036$ & $0.041 \pm 0.027$ & NA & $0.118 \pm 0.035$ & $1.87 \pm 0.58$ & $0.074 \pm 0.095$ & ND & $0.206 \pm 0.021$ \\
\hline${ }^{118} \mathrm{Sn}$ & $9.7 \pm 1.03$ & $4.21 \pm 0.68$ & $1.8 \pm 0.48$ & $10.0 \pm 2.1$ & $1.16 \pm 0.69$ & ND & ND & ND \\
\hline${ }^{121} \mathrm{Sb}$ & $17.5 \pm 2.1$ & $3.81 \pm 0.48$ & $0.68 \pm 0.165$ & $28.1 \pm 4.6$ & $1.6 \pm 0.30$ & $1.83 \pm 0.82$ & $0.47 \pm 0.282$ & $3.45 \pm 0.26$ \\
\hline${ }^{133} \mathrm{Cs}$ & $7.8 \pm 3.05$ & $4.13 \pm 1.29$ & $0.73 \pm 0.353$ & $4.27 \pm 0.86$ & $7.3 \pm 0.80$ & $1.56 \pm 0.99$ & $1.71 \pm 1.19$ & $4.52 \pm 0.81$ \\
\hline${ }^{137} \mathrm{Ba}$ & $38600 \pm 18700$ & $13600 \pm 4300$ & $1950 \pm 774$ & $1810 \pm 279$ & $10000 \pm 7050$ & $4140 \pm 2800$ & $852 \pm 254$ & $4980 \pm 1850$ \\
\hline${ }^{184} \mathrm{~W}$ & $13.3 \pm 2.5$ & $5.41 \pm 0.75$ & $2.24 \pm 0.32$ & $8.40 \pm 1.69$ & $1.53 \pm 0.17$ & $6.8 \pm 2.69$ & $0.897 \pm 0.396$ & $2.9 \pm 0.42$ \\
\hline${ }^{197} \mathrm{Au}$ & $0.11 \pm 0.033$ & $0.248 \pm 0.051$ & $0.04 \pm 0.02$ & $0.254 \pm 0.038$ & $0.037 \pm 0.014$ & $0.009 \pm 0.006$ & $0.016 \pm 0.006$ & $0.011 \pm 0.004$ \\
\hline${ }^{205} \mathrm{Tl}$ & $31 \pm 24.1$ & $17.7 \pm 8.7$ & $1.39 \pm 0.66$ & $3.15 \pm 0.51$ & $1.07 \pm 0.65$ & $2.96 \pm 1.04$ & $9.11 \pm 10.69$ & $5.47 \pm 1.44$ \\
\hline${ }^{206} \mathrm{~Pb}$ & $4720 \pm 2300$ & $1980 \pm 338$ & $283 \pm 19$ & $5870 \pm 4580$ & $691 \pm 161$ & $956 \pm 413$ & $262 \pm 99$ & $1110 \pm 131$ \\
\hline${ }^{207} \mathrm{~Pb}$ & $5970 \pm 2950$ & $1580 \pm 269$ & $258 \pm 16$ & $9380 \pm 5260$ & $652 \pm 152$ & $891 \pm 382$ & $245 \pm 93$ & $1050 \pm 126$ \\
\hline${ }^{208} \mathrm{~Pb}$ & $5400 \pm 2700$ & $2070 \pm 337$ & $275 \pm 19$ & $8700 \pm 4870$ & $670 \pm 157$ & NA & $245 \pm 92$ & NA \\
\hline${ }^{209} \mathrm{Bi}$ & $0.759 \pm 0.104$ & $0.472 \pm 0.077$ & $0.187 \pm \quad 0.035$ & $0.759 \pm 0.155$ & $0.257 \pm 0.078$ & $0.632 \pm 0.281$ & $0.17 \pm 0.057$ & $0.762 \pm 0.123$ \\
\hline${ }^{232} \mathrm{Th}$ & $92.2 \pm 12.5$ & $107 \pm 10$ & $9.03 \pm 2.7$ & $57 \pm 9.1$ & $15.7 \pm 4.6$ & $21.9 \pm 10.1$ & $4.09 \pm 2.24$ & $27.1 \pm 3.3$ \\
\hline${ }^{238} \mathrm{U}$ & $7.88 \pm 1.57$ & $7.01 \pm 1.02$ & $1.52 \pm 0.48$ & $11.4 \pm 3.2$ & $0.711 \pm 0.251$ & $4.12 \pm 2.63$ & $0.638 \pm 0.433$ & $5.09 \pm 0.83$ \\
\hline
\end{tabular}

Each column represents data from 3 separate 3-run analyses using $100 \mu \mathrm{m}$ beam; NA = Not Available; ND = Not Detected, SD = Standard Deviation.

Table 7C. Quadrupole LA-ICPMS Data from Desert Varnish Samples

\begin{tabular}{|c|c|c|c|c|c|c|c|}
\hline Isotope & $\begin{array}{c}\text { MPP 10 } \\
\left(\mu g \times g^{-1}\right) \pm \text { SD }\end{array}$ & $\begin{array}{c}\text { RGPP 1 } \\
\left(\mu \mathrm{g} \times \mathrm{g}^{-1}\right) \pm \mathrm{SD}\end{array}$ & $\begin{array}{c}\text { RGPP 2 } \\
\left(\mu \mathrm{g} \times \mathrm{g}^{-1}\right) \pm \mathrm{SD}\end{array}$ & $\begin{array}{c}\text { RGPP 3 } \\
\left(\mu \mathrm{g} \times \mathrm{g}^{-1}\right) \pm \mathrm{SD}\end{array}$ & $\begin{array}{c}\text { RGPP 4 } \\
\left(\mu \mathrm{g} \times \mathrm{g}^{-1}\right) \pm \mathrm{SD}\end{array}$ & $\begin{array}{c}\text { RGPP 5 } \\
\left(\mu \mathrm{g} \times \mathrm{g}^{-1}\right) \pm \mathrm{SD}\end{array}$ & $\begin{array}{c}\text { RGPP 6 } \\
\left(\mu \mathrm{g} \times \mathrm{g}^{-1}\right) \pm \mathrm{SD}\end{array}$ \\
\hline${ }^{9} \mathrm{Be}$ & $3.72 \pm 0.84$ & $12.3 \pm 1.8$ & $2.47 \pm 0.8$ & $4.36 \pm 0.59$ & $16.9 \pm 6.6$ & $23.4 \pm 2.0$ & $12.9 \pm 1.7$ \\
\hline${ }^{51} \mathrm{~V}$ & $244 \pm 51$ & $74.7 \pm 12.0$ & $76.0 \pm 25.2$ & $86.7 \pm 9.3$ & $61.6 \pm 38.1$ & $52.6 \pm 16.6$ & $191 \pm 19$ \\
\hline${ }^{52} \mathrm{Cr}$ & $38.1 \pm 7$ & $13.3 \pm 0.2$ & $18.8 \pm 6.5$ & $29.8 \pm 6.2$ & $38.7 \pm 37$ & $11.4 \pm 0.7$ & $94.5 \pm 12.0$ \\
\hline${ }^{59} \mathrm{Co}$ & $159 \pm 29$ & $204 \pm 17$ & $123 \pm 45$ & $169 \pm 0$ & $296 \pm 226$ & $149 \pm 9$ & $479 \pm 109$ \\
\hline${ }^{60} \mathrm{Ni}$ & $71.7 \pm 16.1$ & $37.6 \pm 10.7$ & $70.7 \pm 36.2$ & $74.6 \pm 6.4$ & $198 \pm 132$ & $122 \pm 19$ & $206 \pm 31$ \\
\hline${ }^{65} \mathrm{Cu}$ & NA & $68.2 \pm 15.9$ & $55.1 \pm 24.9$ & $40.1 \pm 0.9$ & NA & NA & NA \\
\hline${ }^{66} \mathrm{Zn}$ & $205 \pm 46$ & $869 \pm 143$ & $375 \pm 170$ & $178 \pm 24$ & $465 \pm 182$ & $476 \pm 23$ & $552 \pm 54$ \\
\hline${ }^{88} \mathrm{Sr}$ & $1520 \pm 612$ & $327 \pm 116$ & $241 \pm 16$ & $906 \pm 74$ & $216 \pm 175$ & $154 \pm 27$ & $197 \pm 26$ \\
\hline${ }^{98} \mathrm{Mo}$ & $8.64 \pm 2.07$ & $10.7 \pm 0.7$ & $2.41 \pm 0.69$ & $10.9 \pm 1.2$ & $1.84 \pm 1.23$ & $3.29 \pm 0.77$ & $12.8 \pm 2.8$ \\
\hline${ }^{107} \mathrm{Ag}$ & $0.972 \pm 0.282$ & $0.639 \pm 0.089$ & $0.45 \pm 0.155$ & $0.416 \pm 0.396$ & $1.63 \pm 0.63$ & $1.92 \pm 0.28$ & $1.29 \pm 0.38$ \\
\hline${ }^{111} \mathrm{Cd}$ & $8.09 \pm 3.67$ & $19.8 \pm 1.9$ & $11.3 \pm 6.0$ & $2.12 \pm 0.24$ & $20.7 \pm 12.4$ & $14.4 \pm 1.0$ & $39.8 \pm 4.7$ \\
\hline${ }^{115} \mathrm{In}$ & $0.169 \pm 0.04$ & $0.028 \pm 0.021$ & $0.010 \pm 0.031$ & NA & $0.059 \pm 0.157$ & $0.2 \pm 0.028$ & $0.342 \pm 0.107$ \\
\hline${ }^{118} \mathrm{Sn}$ & $1.15 \pm 1.25$ & $11.3 \pm 1.1$ & $4.46 \pm 0.86$ & $1.35 \pm 0.88$ & ND & $12.2 \pm 1.3$ & $9.21 \pm 3.58$ \\
\hline${ }^{121} \mathrm{Sb}$ & $4.17 \pm 0.56$ & $2.97 \pm 0.98$ & $4.44 \pm 1.11$ & $1.62 \pm 0.7$ & $2.88 \pm 1.52$ & $6.33 \pm 3.56$ & $9.02 \pm 1.58$ \\
\hline${ }^{133} \mathrm{Cs}$ & $3.93 \pm 0.22$ & $5.4 \pm 0.42$ & $2.25 \pm 0.65$ & $6.54 \pm 1.69$ & $8.54 \pm 4.16$ & $8.5 \pm 0.05$ & $21.1 \pm 1.4$ \\
\hline${ }^{137} \mathrm{Ba}$ & $16800 \pm 6960$ & $3610 \pm 52$ & $5300 \pm 1940$ & $32300 \pm 1280$ & $3450 \pm 1880$ & $4710 \pm 1560$ & $5360 \pm 893$ \\
\hline${ }^{184} \mathrm{~W}$ & $6.39 \pm 1.96$ & $7.34 \pm 1.09$ & $9.34 \pm 3.35$ & $4.67 \pm 0.97$ & $13.2 \pm 16.5$ & $72.3 \pm 70.6$ & $18.5 \pm 2.9$ \\
\hline${ }^{197} \mathrm{Au}$ & $0.329 \pm 0.524$ & $0.334 \pm 0.069$ & $0.079 \pm 0.06$ & $0.099 \pm 0.093$ & $0.03 \pm 0.021$ & $0.037 \pm 0.008$ & $0.055 \pm 0.043$ \\
\hline${ }^{205} \mathrm{Tl}$ & $14.7 \pm 1.2$ & $13.1 \pm 1.0$ & $2.24 \pm 1.57$ & $2.87 \pm 0.61$ & $31.5 \pm 17.8$ & $27.3 \pm 7.7$ & $26.9 \pm 4.3$ \\
\hline${ }^{206} \mathrm{~Pb}$ & $1360 \pm 223$ & $4560 \pm 975$ & $806 \pm 161$ & $600 \pm 69$ & $1230 \pm 863$ & $2130 \pm 55$ & $1770 \pm 449$ \\
\hline${ }^{207} \mathrm{~Pb}$ & $1260 \pm 211$ & $3610 \pm 758$ & $898 \pm 0$ & $552 \pm 60$ & $1140 \pm 813$ & $1990 \pm 54$ & NA \\
\hline${ }^{208} \mathrm{~Pb}$ & $1150 \pm 201$ & $4680 \pm 987$ & $760 \pm 149$ & $565 \pm 61$ & NA & NA & NA \\
\hline${ }^{209} \mathrm{Bi}$ & $1.32 \pm 0.28$ & $0.457 \pm 0.111$ & $0.44 \pm 0.08$ & $0.101 \pm 0.008$ & $0.799 \pm 0.669$ & $1.49 \pm 0.05$ & $1.06 \pm 0.28$ \\
\hline${ }^{232} \mathrm{Th}$ & $60.9 \pm 6.1$ & $78.3 \pm 8.9$ & $37.8 \pm 8.5$ & $44.5 \pm 1.6$ & $52.4 \pm 36.1$ & $77.1 \pm 10.9$ & $117 \pm 6$ \\
\hline${ }^{238} \mathrm{U}$ & $18.3 \pm 3.8$ & $7.2 \pm 1.5$ & $1.97 \pm 0.88$ & $3.87 \pm 1.19$ & $6.88 \pm 6.1$ & $14.7 \pm 2.1$ & $20.4 \pm 0.9$ \\
\hline
\end{tabular}




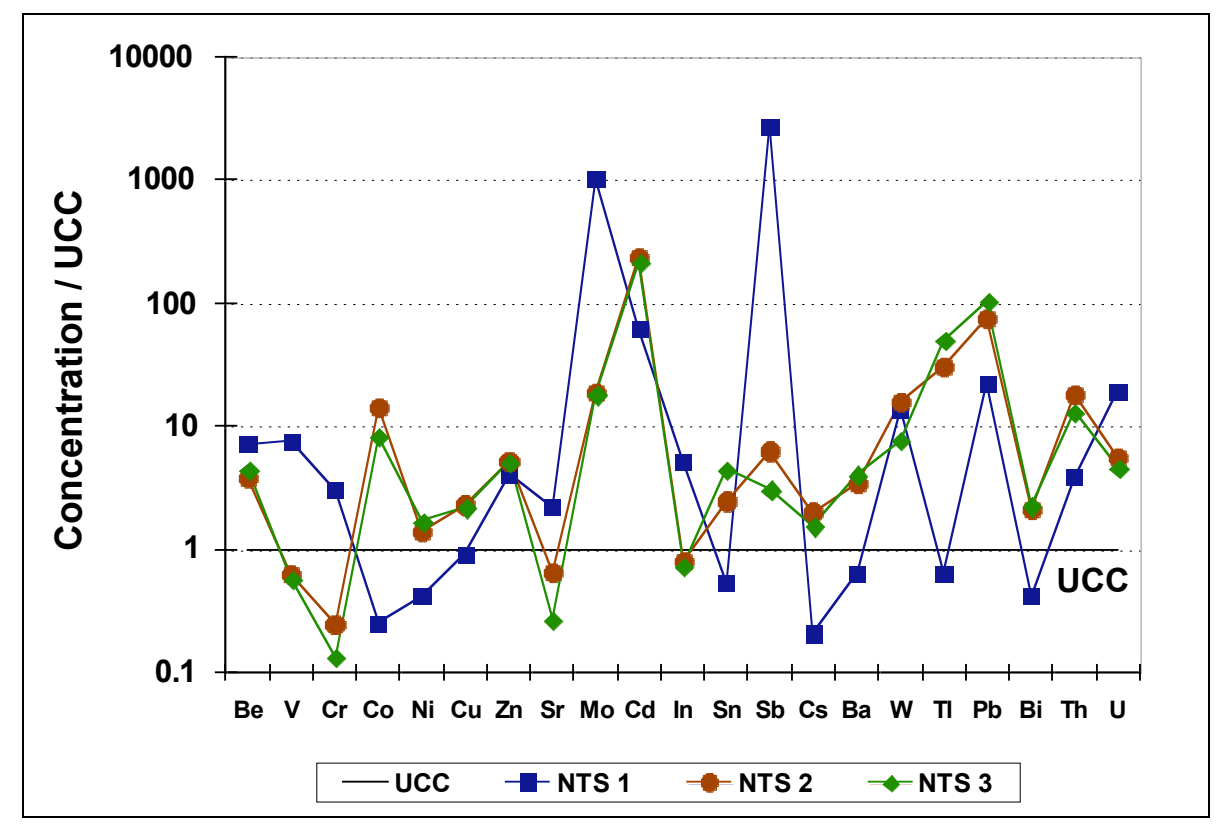

Fig. (3). Abundances of elements in the varnish coatings of NTS samples analyzed by quadrupole LA-ICPMS and normalized to the UCC values. The thick black line represents the average UCC abundance (Ratio=1).

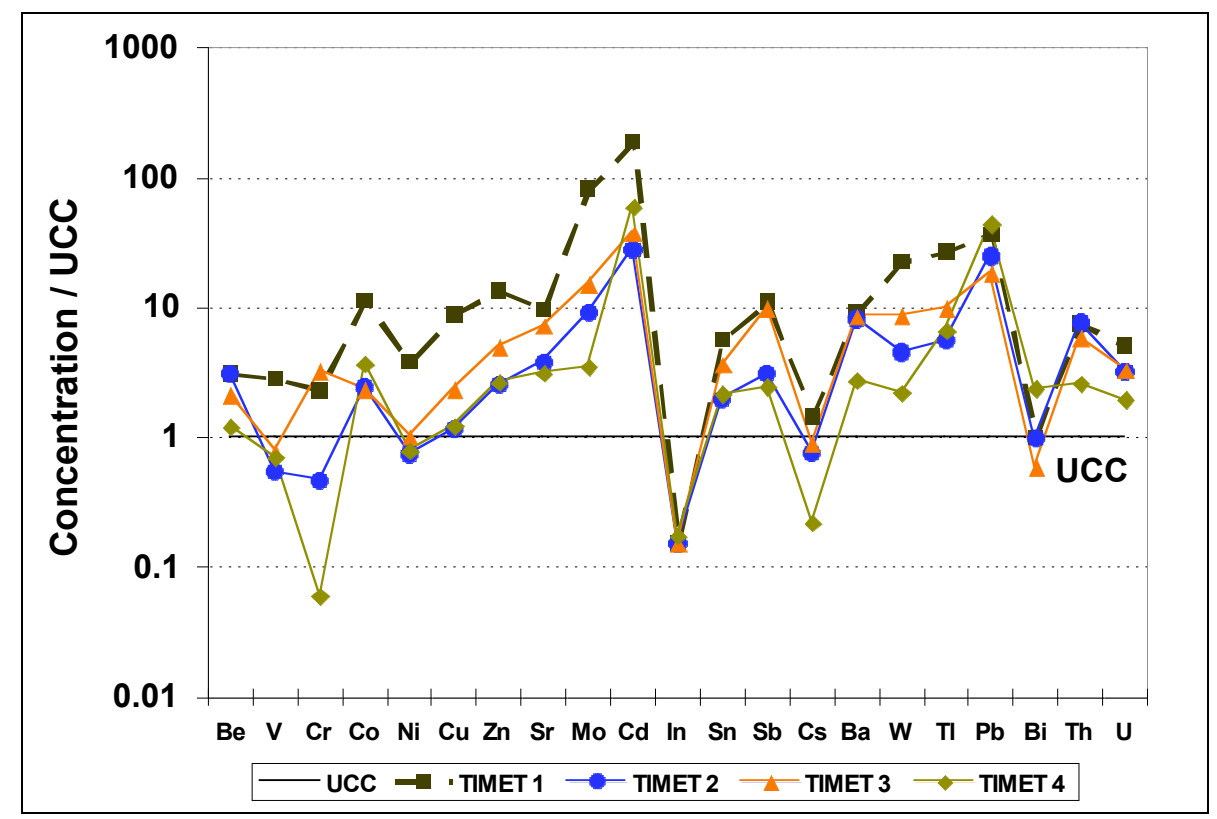

Fig. (4). Abundances of elements in the varnish coatings of TIMET samples analyzed by quadrupole LA-ICPMS and normalized to the UCC values. The thick black line represents the average UCC abundance (Ratio=1).

The samples NTS 2 and NTS 3 are enriched with $\mathrm{Cd}>$ $\mathrm{Pb}>\mathrm{Tl}>\mathrm{Mo}>\mathrm{Th}>\mathrm{W}>\mathrm{Co}>\mathrm{Sb}>\mathrm{U}>\mathrm{Zn}>\mathrm{Be}>\mathrm{Ba}>\mathrm{Sn}$ $>\mathrm{Cu}>\mathrm{Bi}>\mathrm{Cs}>\mathrm{Ni}$. Both NTS 2 and NTS 3 are highly enriched in $\mathrm{Cd}, \mathrm{Tl}$, and $\mathrm{Pb}$. Depleted elements include $\mathrm{V}, \mathrm{Cr}$, $\mathrm{Sr}$, and In. All three NTS samples are enriched in Mo and W, which could be explained by their location in the W mineralization belt. Large quantities of $\mathrm{W}$ have been dispersed into the environment in central Nevada as a result of $\mathrm{W}$ mining and smelting operations $[12,24]$.

The TIMET samples show enrichment of $\mathrm{Cd}>\mathrm{Pb}>\mathrm{Mo}>$ $\mathrm{Tl}>\mathrm{Co}>\mathrm{Sr}>\mathrm{Ba}>\mathrm{Zn}>\mathrm{Th}>\mathrm{Sb}>\mathrm{W}>\mathrm{Sn}>\mathrm{U}>\mathrm{Cu}>\mathrm{Be}$, ranging from 28 to 192 times more than in the $\mathrm{UCC}$ for $\mathrm{Cd}$, and from 1.2 to 3 times more for Be (Fig. 4). Vanadium, Cr, Ni, In, $\mathrm{Cs}$, and $\mathrm{Bi}$ show variable enrichment and depletion.

Cadmium and $\mathrm{Pb}$ have the highest enrichment in all MPP samples, ranging from 39 to 465 times that of the UCC for $\mathrm{Cd}$, and from 15 to 345 times for Pb (Fig. 5). All MPP samples also show an enrichment of 3 to 87 times more than the $\mathrm{UCC}$ values for $\mathrm{Tl}>\mathrm{Co}>\mathrm{Mo}>\mathrm{Ba}>\mathrm{Zn}>\mathrm{Ni}>\mathrm{Sb}$. Antimony, W and Th are depleted only in MPP 8. Beryllium, $\mathrm{V}, \mathrm{Cr}, \mathrm{Cu}, \mathrm{Sr}, \mathrm{In}, \mathrm{Sn}, \mathrm{Cs}, \mathrm{Bi}$, and $\mathrm{U}$ show variable enrichment and depletion.

The RGPP samples show enrichment of $\mathrm{Cd}>\mathrm{Pb}>\mathrm{Tl}>>$ $\mathrm{Co}>\mathrm{Mo}>\mathrm{W}>\mathrm{Th}>\mathrm{Ba}>\mathrm{Sb}>\mathrm{Zn}>\mathrm{Be}>\mathrm{Ni}$, ranging from 35 


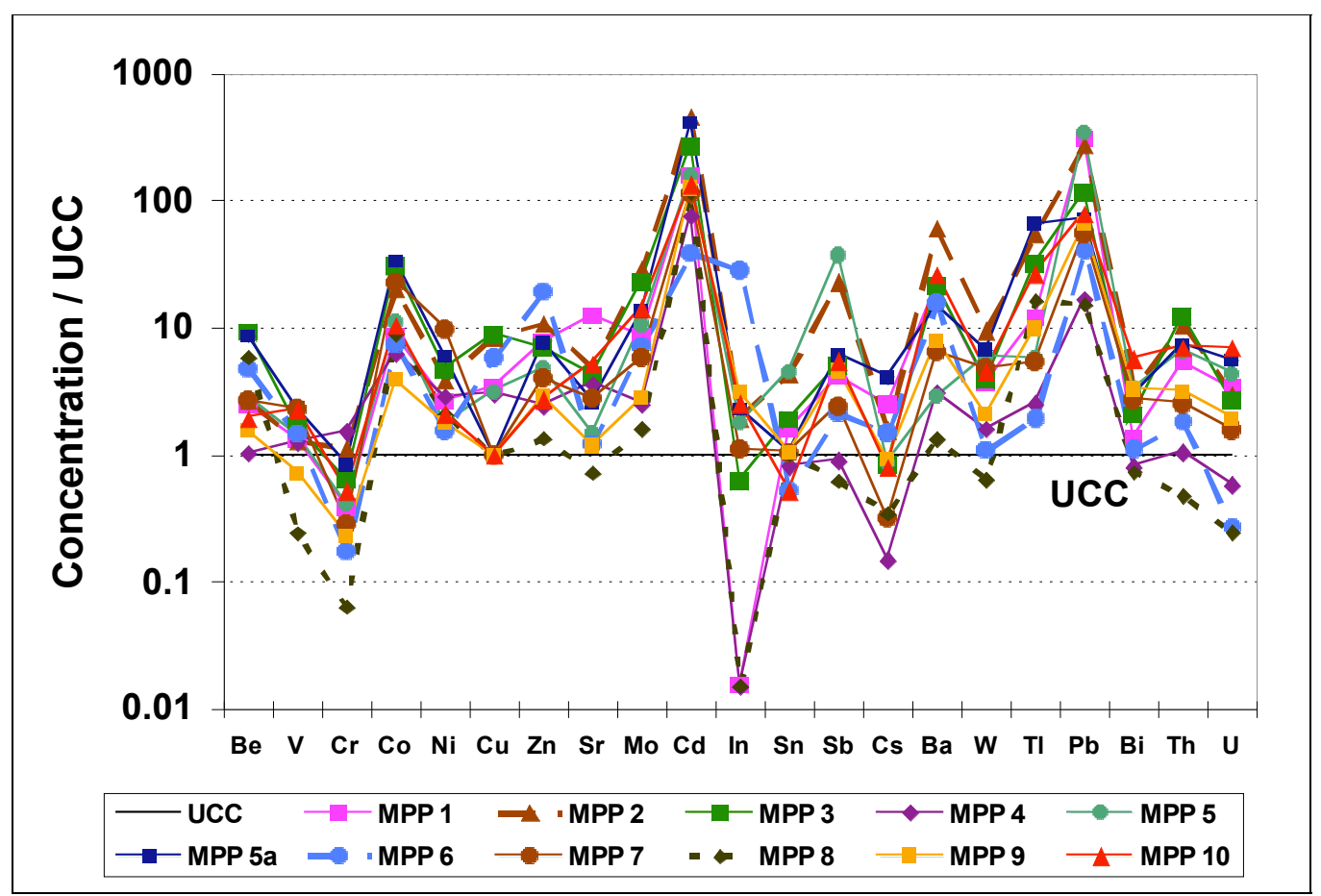

Fig. (5). Abundances of elements in the varnish coatings of MPP samples analyzed by quadrupole LA-ICPMS and normalized to the UCC values. The thick black line represents the average UCC abundance (Ratio=1).

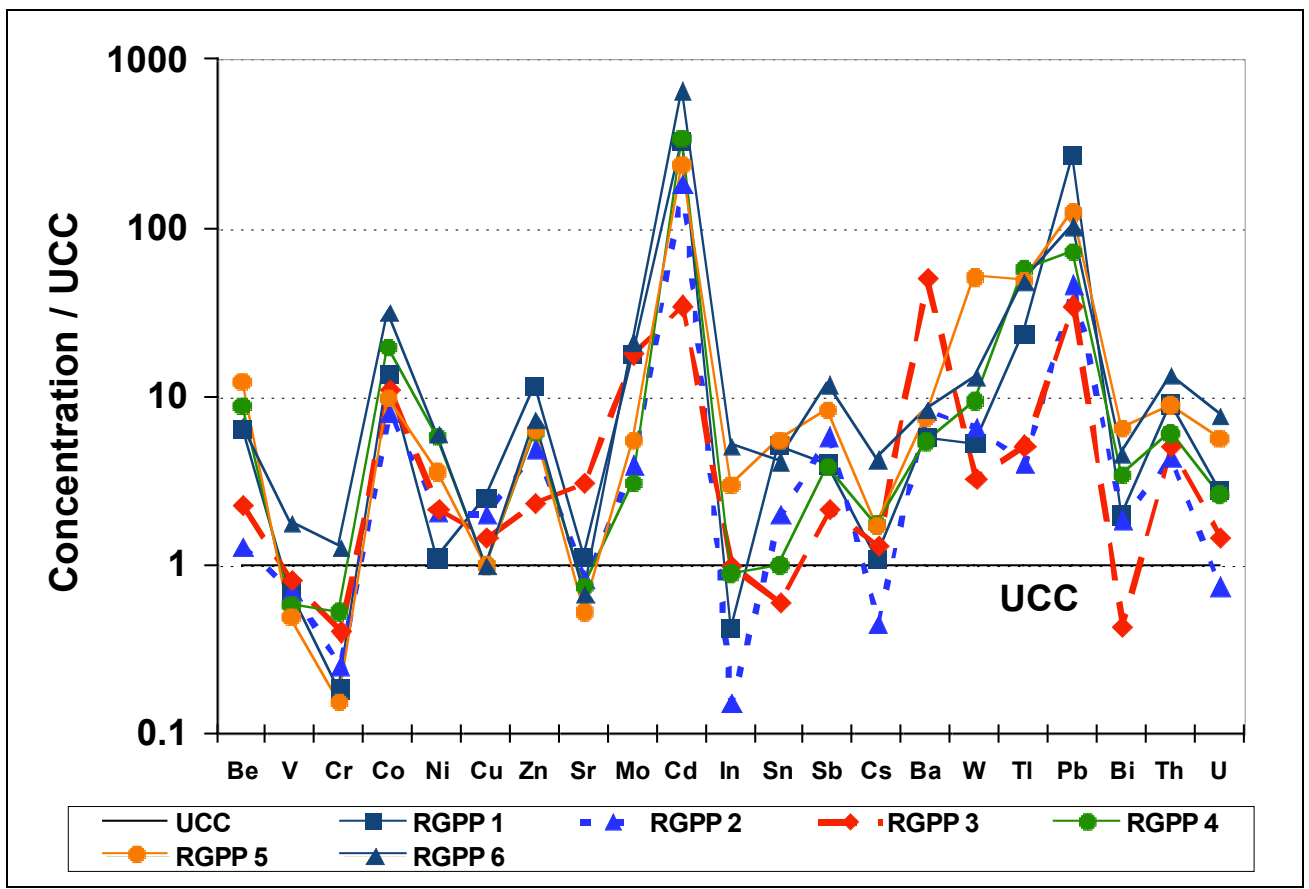

Fig. (6). Abundances of elements in the varnish coatings of RGPP samples analyzed by quadrupole LA-ICPMS and normalized to the UCC values. The thick black line represents the average UCC abundance (Ratio=1).

to 663 times more than the UCC for Cd, and from 1.1 to 6 times more for $\mathrm{Ni}$ (Fig. 6). Cesium and $\mathrm{U}$ are depleted only in RGPP 2; $\mathrm{Sn}$ and $\mathrm{Bi}$ are depleted only in RGPP 3. Vanadium, $\mathrm{Cr}, \mathrm{Sr}$ and In show variable enrichment and depletion.

\subsection{Trace Metal Concentrations and the Distance from Power Plants}

Many elements that have high concentrations in varnish coatings are frequently found in fly ash emitted from coal- fired power plants [25-29]. The concentrations of the elements (V, Cr, Co, Ni, Cu, Zn, Cd, Sn, Sb, Tl and Pb) were plotted as a function of the distance from each power plant (Figs. 7-10). The distances north of the plant were entered as positive numbers and the distances south of the plant were entered as negatives.

The MPP graphs point to deposition areas at distances of 50 to $80 \mathrm{~km}$ south of the power plant and 40 to $100 \mathrm{~km}$ north of the power plant (Figs. 7, 8). The RGPP graphs display 
deposition areas at distances of 50 to $80 \mathrm{~km}$ north of the power plant and 40 to $80 \mathrm{~km}$ south of the power plant. Noticeably, extremely southern and northern points of the graph show concentration increases. The point (MPP 2) is located in the deposition area of the MPP and probably includes influxes of particulates from both MPP and RGPP. On the other hand, the northern point (NTS 1) is located near the NTS and within the $\mathrm{W}$ mineralization belt. The sampled rocks may present unique geological composition that is demonstrated by the high abundance of As, Mo and Sb (Figs. 9, 10).

Both graphs show a general pattern. Lower concentrations are observed at the source followed by a maximum peak concentration and gradual decrease with the distance from the power plant. The observed patterns are consistent with the predictions of the Gaussian Plume atmospheric transport and diffusion model used to calculate average ground level concentrations of the deposited

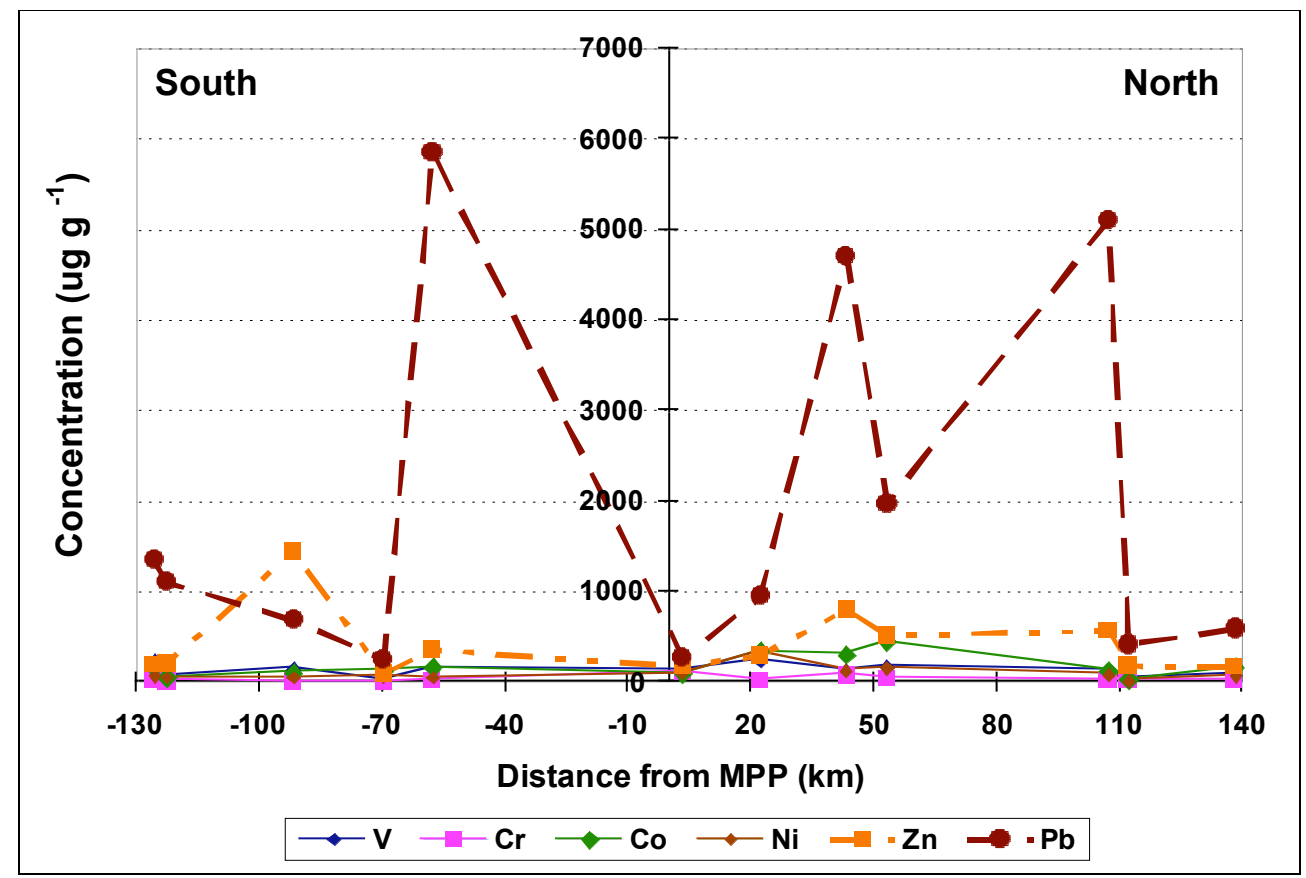

Fig. (7). Concentrations of $\mathrm{V}, \mathrm{Cr}, \mathrm{Co}, \mathrm{Ni}, \mathrm{Zn}$, and $\mathrm{Pb}$ by quadrupole LA-ICPMS analysis of desert varnish samples as a function of distance from the MPP.

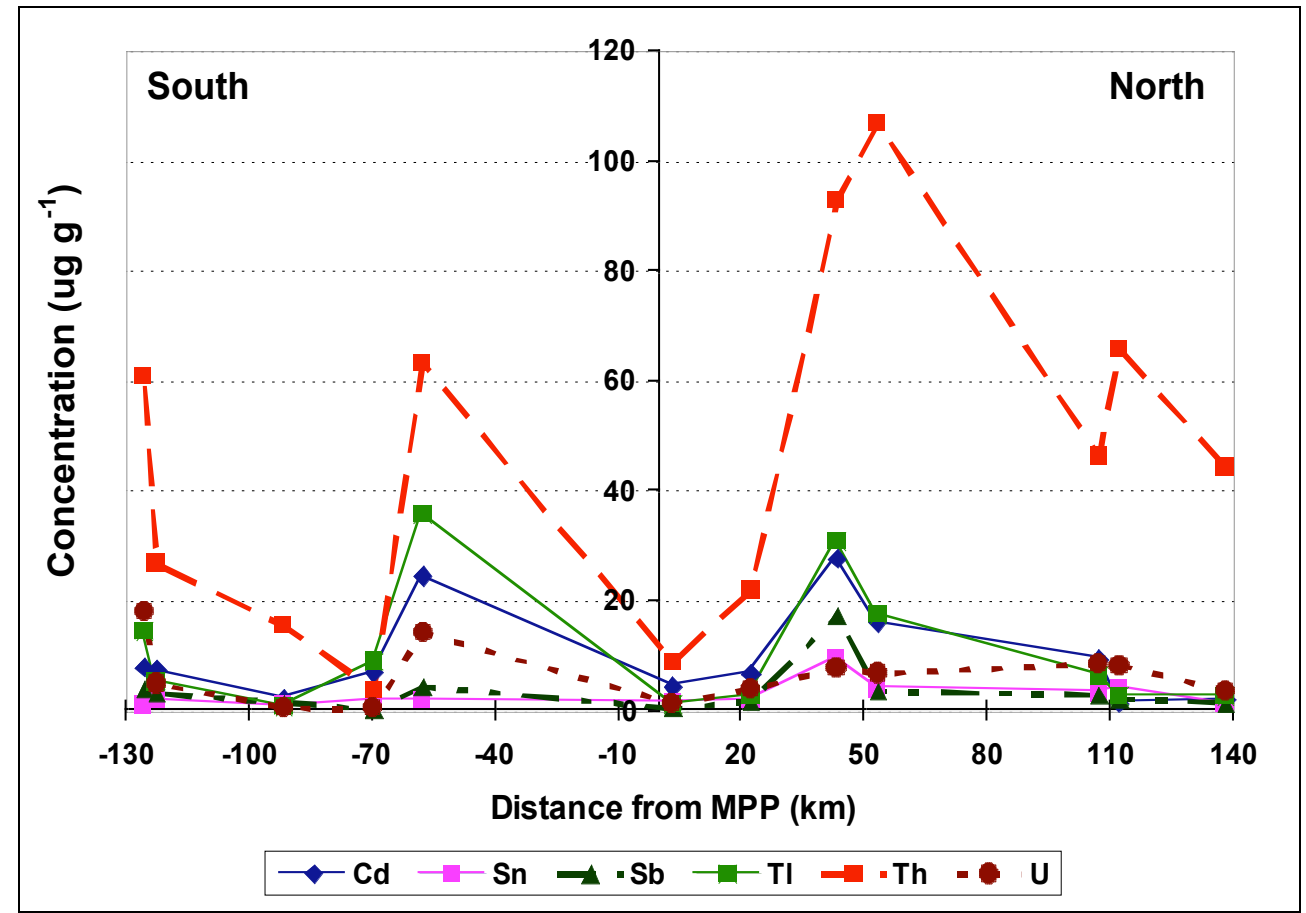

Fig. (8). Concentrations of Cd, Sn, Sb, Tl, Th, and U by quadrupole LA-ICPMS analysis of desert varnish samples as a function of distance from the MPP. 


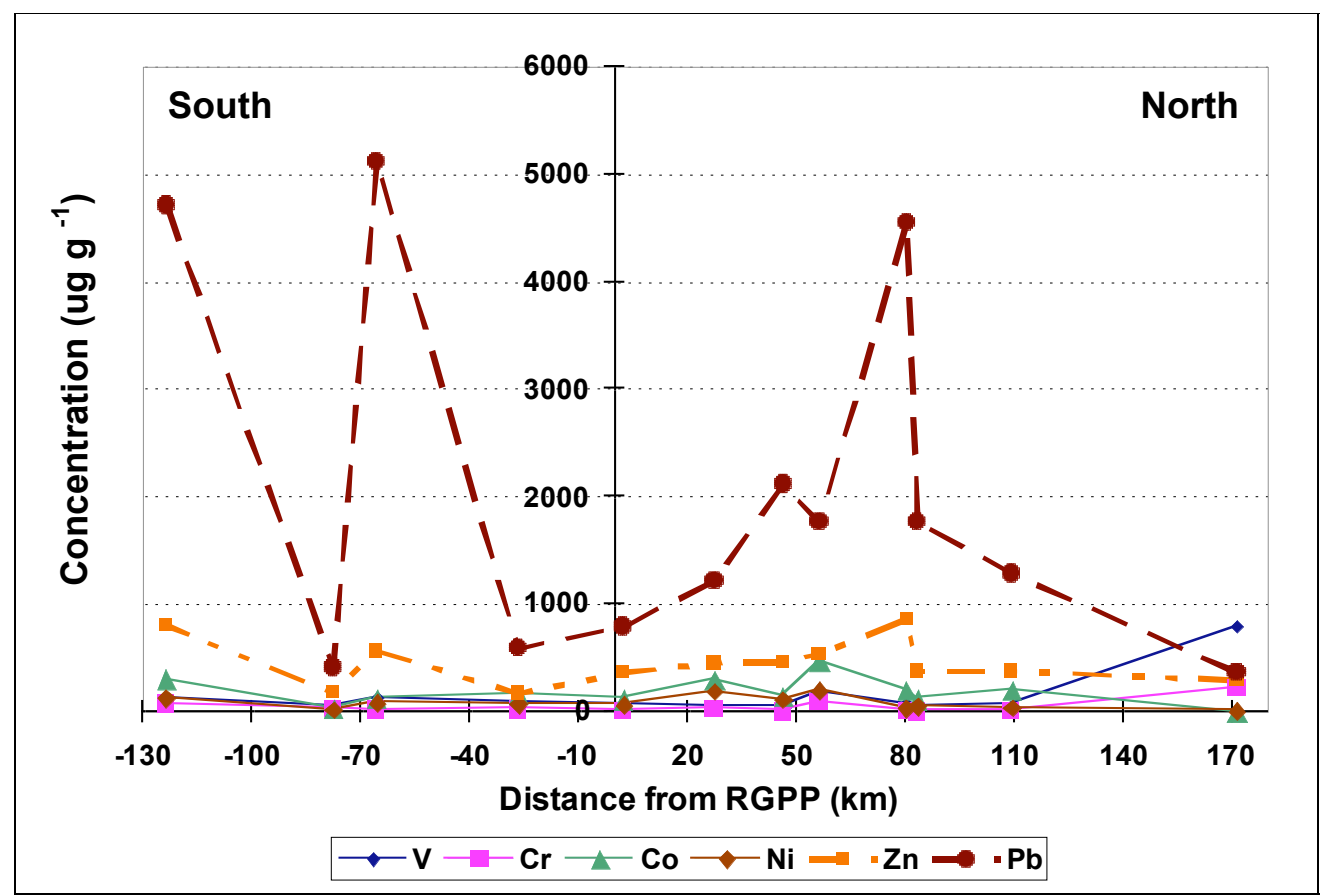

Fig. (9). Concentrations of $\mathrm{V}, \mathrm{Cr}, \mathrm{Co}, \mathrm{Ni}, \mathrm{Zn}$, and $\mathrm{Pb}$ by quadrupole LA-ICPMS analysis of desert varnish samples as a function of distance from the RGPP.

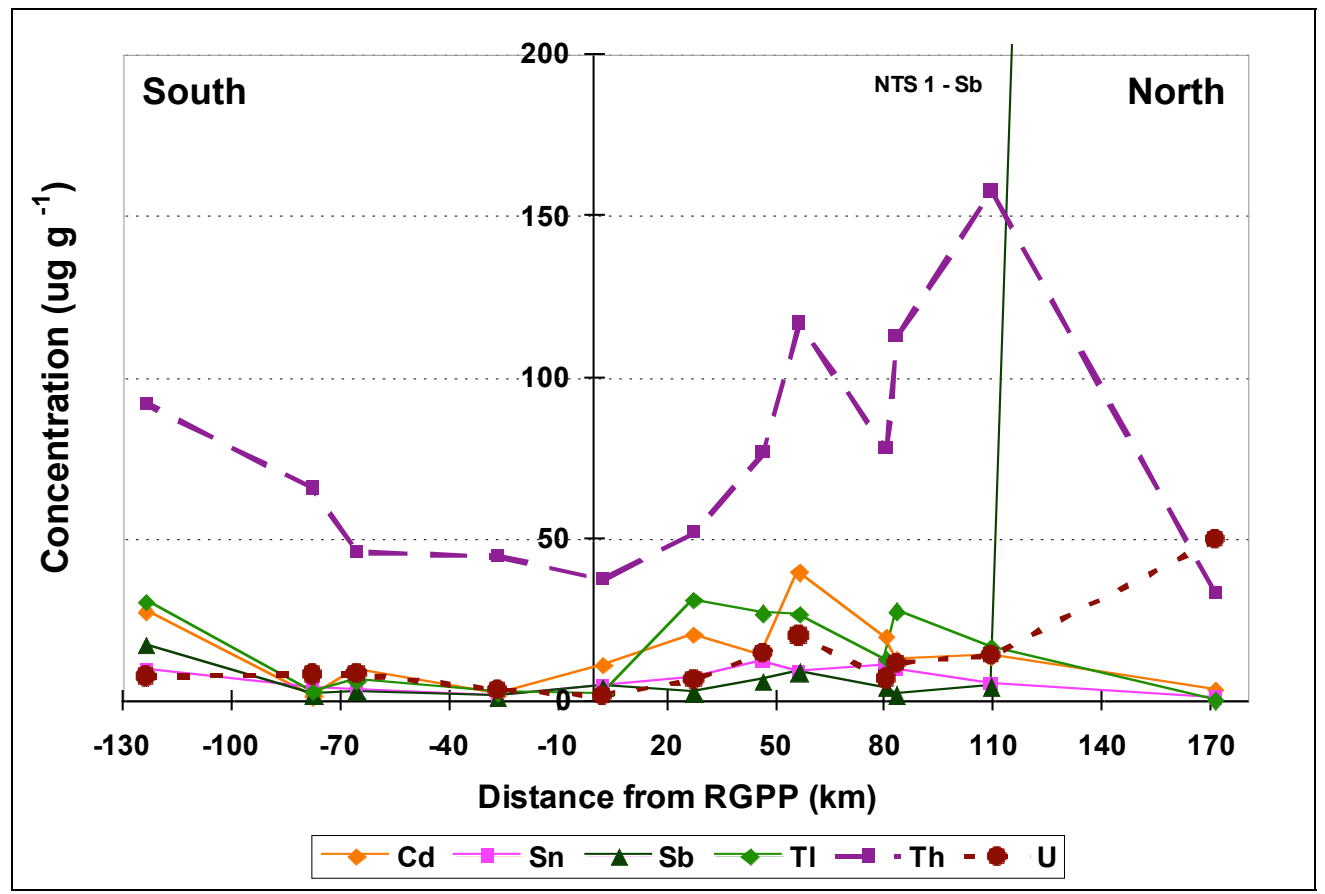

Fig. (10). Concentrations of $\mathrm{Cd}, \mathrm{Sn}, \mathrm{Sb}, \mathrm{Tl}, \mathrm{Th}$, and $\mathrm{U}$ by quadrupole LA-ICPMS analysis of desert varnish samples as a function of distance from the RGPP. The black vertical line at $110 \mathrm{~km}$ north of the RGPP represents the off-scale Sb concentration in NTS 1 at $2070 \mu \mathrm{g} \cdot \mathrm{g}^{-1}$.

pollutants [16]. The plume deposition model assumes that beyond the distance of maximum deposition, trace element concentrations in soils should decrease with increasing distance from the power plant if the power plant is a significant source of that element. An area of low deposition near the power plant is expected as a result of pollutant release from elevated stacks [16, 30-32].

Interestingly, the MPP peaks with the highest elemental concentrations fall within the MPP maximum deposition areas established during summer and winter tracer release experiments during project MOHAVE [14].

In 1991, the Environmental Protection Agency (EPA), National Park Service (NPS) and Southern California Edison, conducted a monitoring, modeling, and data assessment study designed to estimate the MPP's contributions to haze at the GCNP [14]. This cooperative effort was named Project Measurement of Haze and Visibility Effects, referred to as Project MOHAVE [14]. The 
findings of project MOHAVE caused closure of the MPP in December 2005 [33]. During Project MOHAVE a perfluorocarbon tracer (PFT) was used to establish prevailing wind directions and deposition patterns of the contaminants [14]. At the MPP, the PTF was injected into the power plant stack at a height of $20 \mathrm{~m}$. The tracer, ambient particulate composition, and $\mathrm{SO}_{2}$ concentrations were measured at about 30 locations in the four-state region of Arizona, California, Nevada, and Utah [34].

The modeling of plume deposition patterns from the MPP resulted in the development of the influence functions. The influence functions are a direct measure of the average dispersion between the emission and monitoring locations. The assessment of average dispersion includes calculations of the range, average deviation, variance, and standard deviation of the measured values. The spatial patterns of the mean influence functions illustrate the typical tracer distribution observed throughout each season.

Summer wind flow is generally from the south, along the Colorado River, and from the west (or possible southwest), from the western edge of the Mojave Desert. This is consistent with the predominant summer surface wind flow patterns for California [14]. Consequently, summer MPP average influence function values were highest at sites to the north of the plant. This suggests that MPP emissions during the summer (April through September) consistently occur over most of the area of Lake Mead (north of the MPP along the Colorado River) with relatively little dilution [14]. Three sites were sampled in the summer deposition areas. All three sites were located to north of the MPP along Colorado River Canyon (MPP 1, MPP 2, and MPP 3) (Fig. 1).

A predominant feature of winter airflow shown by the PFT data is drainage down the Colorado River. The largest values of the influence functions were observed during the winter intensive monitoring period (November - February) at sites along the Colorado River Canyon, which acts as a natural conduit for airflow in the winter. Winter airflow for the MPP also follows the Colorado River, with the greatest influence function values to the south of Parker, AZ [14]. The seven sites were sampled in the winter deposition areas. All sites were located to the south of the MPP along the Colorado River Canyon (MPP 4, MPP 5, MPP 6, MPP 7, MPP 8, MPP 9, and MPP 10) (Fig. 1).

\section{CONCLUSIONS}

This study produced preliminary data indicating the utility of rock varnish as a passive environmental monitor of relatively recent events such as atmospheric pollution from coal-fired power plants. Analysis of varnishes thus provides records of atmospheric metals and other possible environmental pollutants such as radionuclides and organic compounds. The analytical data obtained demonstrated that LA-ICPMS can successfully be used for the trace metals analysis of varnish samples. Consequently, rock varnish deserves further study as a passive environmental monitor. Future varnish studies should focus on the implementation of a detailed plan to analyze a large number of samples from the deposition area of the point source of air pollution. The large number of samples will make it possible to distinguish regional signals from the local noise.
Analysis of varnishes is a new field that can potentially provide records of pre-anthropogenic levels of atmospheric metals and other environmental pollutants. The data provided basic knowledge of the chemical composition of varnish coatings and, thus, additional evidence to help understand the mechanism of varnish formation. The results of this study will have implications 1) for mapping the distribution of trace element air contamination, 2) for identifying the sources of air pollution, 3 ) for deciphering the history of atmospheric pollution, and 4) for contributing to our understanding of desert varnish formation.

In brief, even though desert varnish is slow-growing, it very effectively accumulates ambient air-borne materials and preserves them in its matrix for some, yet undetermined, lifetime. The trace element fingerprints held in the desert varnish may be useful in identifying sources of natural or anthropogenic air pollution.

\section{ACKNOWLEDGEMENTS}

The authors would like to thank Harry Reid Center for Environmental Studies at the University of Nevada Las Vegas for allowing using their facilities to conduct this work.

\section{REFERENCES}

[1] Krinsley, D. Models of rock varnish formation constrained by high resolution transmission electron microscopy. Sedimentology, 1998, 45, 711-725

[2] Liu, T.; Broecker, W.S. How fast does rock varnish grow? Geology, 2000, 28(2), 183-186.

[3] Perry, R.S.; Adams, J. Desert varnish - evidence for cyclic deposition of manganese. Nature, 1978, 276, 489-491.

[4] Fleisher, M.; Liu, T.; Broecker, W.S.; Moore, W. A clue regarding the origin of rock varnish. Geophys. Res. Lett., 1999, 26(1), 103106.

[5] Broecker, W.S.; Liu, T. Rock varnish: Recorder of desert wetness? GSA Today, 2001, 11(8), 4-10.

[6] Moore, W.S.; Liu, T.; Broecker, W.S.; Finkel, R.C.; Wright, A. Factors influencing Be-7 accumulation on rock varnish. Geophys. Res. Lett., 2001, 28(23), 4475- 4478.

[7] Bao, H.; Michalski, G.M.; Thiemens, M.H. Sulfate oxygen-17 anomalies in desert varnishes. Geochimica et Cosmochimica Acta, 2001, 65(13), 2029-2036.

[8] Hodge, V.F.; Farmer, D.E.; Diaz, T.A.; Orndorff, R.L, Prompt detection of alpha particles from Po-210: another clue to the origin of rock varnish? J. Environ. Radioact., 2005, 78(2005), 331-342.

[9] Dorn, R.I. In: Geochemical Sediments and Landscapes; Blackwell: New York, 2007, pp. 246-290.

[10] Tebo, B. M.; Bargar, J.R.; Clement, G.J.; Gregory, J.D.; Murray, K.J. Biogenic manganese oxides: Properties and mechanisms of formation. Annual Rev. Earth Planet. Sci., 2004, 32, 287-328.

[11] Thiagarajan, N.; Lee, C.A. Trace-element evidence for the origin of desert varnish by direct aqueous atmospheric deposition. Earth Planet. Sci. Lett., 2004, 224 (2004), 131-141.

[12] Wayne, D.M.; Diaz, T.A.; Fairhurst, R.J.; Orndorff, R.L.; Pete, D.V. Direct major- and trace-element analyses of rock varnish by high resolution laser ablation inductively-coupled plasma mass spectrometry (LA-ICPMS). Appl. Geochem., 2006, 21(8), 14101431.

[13] Crowder, J.W.; Richards, J.R. Control of Particulate Matter Emissions. Air Pollution Training Institute Course 415, 2003, Student Manual.

[14] U.S. Environmental Protection Agency. Project MOHAVE Final Report. http://www.epa.gov/region09/air/mohave/report.html [Accessed June 23, 2007].

[15] U.S. Department of Energy. (1994, September). Development of the Town Data Base: Estimates of Exposure Rates and Times of Fallout Arrival near the Nevada Test Site (Publication No. DOE/NV-374/UC-702).

[16] Wangen, L.E.; Williams, M.D. Elemental deposition downwind of a coal-fired power-plant. Water Air Soil Pollut., 1978, 10(1), 33-44. 
[17] Nodelman, I.G.; Pisupati, S.V.; Falcone Miller, S.; Sarconi, A.W. Partitioning behavior of trace elements during pilot-scale combustion of pulverized coal and coal-water slurry fuel. J. Haz. Mat., 2000, 74, 47-59.

[18] Nevada Division of Environmental Protection. (2005, September). Fact Sheet Reid Gardner Station, Permit NEV91022. Retrieved June 30, 2007, from NDEP Reports Online via GPO Access: http://ndep.nv.gov/docs_04/nev91022_f05.pdf.

[19] U.S. Environmental Protection Agency. (November, 2003). Technical Support Document: Titanium Metal Corporation, Part 70 TSD, Source 00019. http://yosemite.epa.gov/R9/AIR/EPSS.NSF/ 735056a63c1390e08825657e0075d180/c0a3f63cddb62ef088256df 60061365b!OpenDocument [Accessed June 25, 2007].

[20] Flem, B.; Larsen, R.B.; Grimstvedt, A; Mansfield, J. In situ analysis of trace elements in quartz by using laser ablation inductively coupled plasma mass spectrometry. Chem. Geology, 2002, 182(2002), 237-247.

[21] Kurosawa, M.; Jackson, S.E.; Sueno, S. Trace element analysis of NIST SRM 614 and 616 glass reference materials by laser ablation microprobe-inductively coupled plasma-mass spectrometry. Geostand. Newslett., 2002, 26(1), 75-84.

[22] Miller, J.C.; Miller, J.N. Statistics for Analytical Chemistry. John Wiley \& Sons: New York, 1984.

[23] Seames, W.S.; Wendt, J.O.L. Partitioning of arsenic, selenium, and cadmium during the combustion of Pittsburgh and Illinois \#6 coals in a self-sustained combustor. Fuel Process. Tech., 2000, 63(2), 179-196.

[24] Furimski, E. Characterization of trace element emission from coal combustion by equilibrium calculations. Fuel Process. Tech., 2000, 63, 29-44.
[25] Martines-Tarazona, M.R.; Spears, D.A. The fate of trace elements and bulk minerals in pulverized coal combustion in a power station. Fuel Process. Tech., 1996, 47, 79-92.

[26] Zeng, T.; Sarofim, A.F.; Senior, C.L. Vaporization of arsenic, selenium and antimony during coal combustion. Combust. Flame, 2001, 126, 1714-1724

[27] Danihelka, P.; Volna, Z.; Jones, J.M.; Williams, A. Emission of trace toxic metals during pulverized fuel combustion of Czech coals. Int. J. Energy Res., 2003, 27, 1181-1203.

[28] Condie, K.C. Chemical composition and evolution of the upper continental crust: contrasting results from surface samples and shales. Chem. Geol., 1993, 104(1993), 1-37.

[29] Danihelka, P.; Volna, Z.; Jones, J.M.; Williams, A. Emission of trace toxic metals during pulverized fuel combustion of Czech coals. Int. J. Energy Res., 2003, 27, 1181-1203.

[30] Anderson, B.M.; Keith, J.R.; Connor, J.J.; In: Geochemical Survey of the Western Coal Regions, Second Annual Progress Report, U.S. Geological Survey Open-file Report No. 75-436, 1975, pp. 50-57.

[31] Connor, J.J.; Anderson, B.M.; Keith, J.R.; Boerngen, J.G.; In Geochemical Survey of the Western Energy Regions, Third Annual Progress Report, U.S. Geological Survey Open-file Report No. 76 729, 1976, pp. 112-120.

[32] Keith, J.R.; Anderson, B.M.; Connor, J.J. In: Geochemical Survey of the Western Coal Regions, First Annual Progress Report, U.S Geological Survey Open-file Report No. 74-250, 1974, pp. 14-29.

[33] Edwards, J. G. Las Vegas Review-Journal, December 24, 2005, http://www.reviewjournal.com [accessed July 12, 2007].

[34] Green, M.C. The project MOHAVE tracer study: study design, data quality, and overview of results. Atmos. Environ., 1999, 33(12), $1955-1968$

(C) Nowinski et al.; Licensee Bentham Open.

This is an open access article licensed under the terms of the Creative Commons Attribution Non-Commercial License (http://creativecommons.org/licenses/by$\mathrm{nc} / 3.0 /$ ) which permits unrestricted, non-commercial use, distribution and reproduction in any medium, provided the work is properly cited. 